\title{
Recent progress in understanding physical and chemical properties of African and Asian mineral dust
}

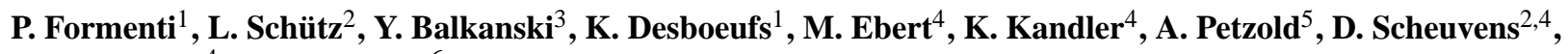 \\ S. Weinbruch ${ }^{4}$, and D. Zhang ${ }^{6}$ \\ ${ }^{1}$ Laboratoire Interuniversitaire des Systèmes Atmosphériques (LISA), UMR7583, Université Paris Est Créteil et Université \\ Paris Diderot, Institut Pierre Simon Laplace, Créteil, France \\ ${ }^{2}$ Institut für Physik der Atmosphäre, Johannes-Gutenberg-Universität, Mainz, Germany \\ ${ }^{3}$ Laboratoire des Sciences du Climat et de l'Environnement (LSCE), CEA-CNRS-UVSQ, Institut Pierre Simon Laplace, \\ L'Orme des Merisiers, France \\ ${ }^{4}$ Institut für Angewandte Geowissenschaften, Technische Universität Darmstadt, Darmstadt, Germany \\ ${ }^{5}$ Deutsches Zentrum für Luft- und Raumfahrt (DLR), Institut für Physik der Atmosphäre Oberpfaffenhofen, \\ Wessling, Germany \\ ${ }^{6}$ Prefectural University of Kumamoto, Kumamoto, Japan
}

Received: 8 November 2010 - Published in Atmos. Chem. Phys. Discuss.: 22 December 2010

Revised: 3 August 2011 - Accepted: 4 August 2011 - Published: 15 August 2011

\begin{abstract}
This paper presents a review of recently acquired knowledge on the physico-chemical properties of mineral dust from Africa and Asia based on data presented and discussed during the Third International Dust Workshop, held in Leipzig (Germany) in September 2008.

Various regional field experiments have been conducted in the last few years, mostly close to source regions or after short-range transport. Although significant progress has been made in characterising the regional variability of dust properties close to source regions, in particular the mineralogy of iron and the description of particle shape and mixing state, difficulties remain in estimating the range of variability of those properties within one given source region. As consequence, the impact of these parameters on aerosol properties like optical properties, solubility, hygroscopicity, etc. determining the dust impact on climate - is only partly understood. Long-term datasets in remote regions such as the dust source regions remain a major desideratum.

Future work should also focus on the evolution of dust properties during transport. In particular, the prediction of the mineral dust size distribution at emission and their evolution during transport should be considered as a high-priority.
\end{abstract}

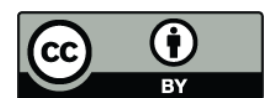

Correspondence to: P. Formenti (formenti@lisa.u-pec.fr)
From the methodological point of view, a critical assessment and standardisation of the experimental and analytical techniques is highly recommended. Techniques to characterize the internal state of mixing of dust particles, particularly with organic material, should be further developed.

\section{Introduction}

The most recent model estimates indicate that global mineral dust emissions by wind-driven erosion over arid and semiarid areas range between 1000 and $3000 \mathrm{Tg} \mathrm{yr}^{-1}$ (Zender et al., 2004; Cakmur et al., 2006; Textor et al., 2007), representing about half of the annual particle emission at the global scale (Forster et al., 2007).

The global dust belt, where dust sources are located, extends from the west coast of North Africa, through the Middle East, into Central Asia and covers the Sahara, the deserts of the Arabian Peninsula and of Oman, Caspian Sea and Aral Sea regions in Central Asia, and Gobi and the Taklimakan in China. Sources outside the global dust belt are located in the USA and Mexico, Lake Eyre and the Great Artesian Basin in Australia, Makgadikgadi Depression and Pans in Botswana and the Namibia desert, both situated in Southern Africa, and Southern American deserts Altiplano in Bolivia, as well as desert areas in Patagonia and in Western Argentina.

Published by Copernicus Publications on behalf of the European Geosciences Union. 
Once in the atmosphere, mineral dust plumes influence the global climate. Dust interacts with radiation by scattering and absorption in the visible and thermal infrared spectral region (Myhre and Stordal, 2001; Balkanski et al., 2007) and may serve as cloud condensation nuclei $(\mathrm{CCN})$ or ice nuclei (IN) (DeMott et al., 2003; van den Heever et al., 2006). Dust also plays a crucial role in fertilizing large areas of the oceans by deposition and subsequent dissolution (Duce et al., 1991; Jickells and Spokes, 2001). Furthermore, mineral dust has a potential impact on human health directly (e.g., Kwon et al., 2002; Perez et al., 2008) and via the spreading of microorganisms (Kellogg and Griffin, 2006), on regional air quality via the visibility impairment (Prospero, 1999) and on the atmospheric composition through heterogeneous reactions (Bauer et al., 2004; de Reus et al., 2005). An example of environmental impact is the demise of Caribbean Coral Reefs, as suggested by Shinn et al. (2000).

As for any type of atmospheric aerosol particles, the environmental and climatic impacts of mineral dust depend on its physico-chemical properties, that is, composition, shape, surface state, size, and mixing state of the particles (Raes et al., 2000a). This link is made explicit in Table 1.

Mineral dust consists of irregular particles, often aggregates of different composition, of sizes varying from tenths of nanometers to hundreds of microns. The size distribution evolves rapidly according to time after emission (Pye, 1987).

Particle size is a fundamental parameter to understand and predict atmospheric lifetime, transport processes and impacts of mineral dust. The representation of the mineral dust size distribution remains a real challenge due to the large size spectrum. The number size distribution, dominated by submicron particles, controls the direct impact on radiation and on cloud processes (Sokolik et al., 2001; Dusek et al., 2006). The mass size distribution, dominated by supermicron particles, controls deposition, hence the biogeochemical effects, as well as interactions with the gas phase (Trochkine et al., 2003; Zhang et al., 2003a). The surface distribution controls radiative effects. Examples with respect to the direct radiative impact are given by Otto et al. (2007) and McConnell et al. (2010).

Particle shape influences the aerosol optical properties underlying the direct effect (Nousiainen, 2009). Deviation of dust grains from spherical shape can change light scattering by a factor of 2, depending on the scattering angle (Kalashnikova and Sokolik, 2002; Dubovik et al., 2006). The uncertainty in remote sensing of dust optical depth due to particle shape could be even higher due to the particle's refractive index (Kahnert et al., 2007). Particle shape, besides size and density, also influences particle sedimentation. In general, sedimentation velocity decreases with increasing deviation from spherical shape (Cheng et al., 1988). For example, flat particles (i.e., particles whose thickness is smaller than the width and length, such as spheroids) can be transported over longer distances than spherical ones. In addition, with increasing non-sphericity the orientation of the particle in the air becomes a factor influencing the sedimentation velocity. While it is generally assumed that flat particles orientate horizontally, it was also suggested that due to an asymmetry of the centre of gravity, the particles may orientate with the heavier part pointing downwards ( $\mathrm{Li}$ and Osada, 2007a, b).

Composition is the third key property. Sokolik and Toon (1999) demonstrated that the variable mineralogical composition (clays, quartz, carbonates, feldspars, sulphates, iron oxides) has to be incorporated into radiative models to estimate the dust optical and radiative properties. When first emitted, dust particles are often composed to a large extent of insoluble or low-solubility components. Referring to Koehler theory, mineral dust particles are considered almost CCN inactive (Kreidenweis et al., 2005). In contrast to this theory-based assumption, several experimental studies suggest that freshly emitted dust particles can serve as $\mathrm{CCN}$ or IN (Koehler et al., 2009; Connolly et al., 2009). The nucleation of cloud droplets on dust particles is most likely influenced by the mineralogical composition, notably on their calcite content for CCN ability (Gustafsson et al., 2005; Gibson et al., 2006), and clay content (kaolinite and illite) for IN efficiency (Zimmermann et al., 2008).

Mostly clay minerals as kaolinite, illite or montmorillonite are thought to dominate the atmospheric nucleation of ice at temperatures below $-12{ }^{\circ} \mathrm{C}$ (e.g., Mason, 1971; Eastwood et al., 2008; Zimmermann et al., 2008). At higher temperatures, biological IN may play an important role as the highest temperatures of ice nucleation were reported for specific bacteria (Schnell and Vali, 1972; Möhler et al., 2007). Elevated IN concentrations were found in Saharan dust plumes transported over long distances to the eastern US (DeMott et al., 2003) and to Europe (Klein et al., 2010). A robust correlation was found between the number concentrations of IN and of the particles above $0.5 \mu \mathrm{m}$ diameter, which are often dominated by mineral dust (DeMott et al., 2010). Recent space observations support this by showing that the fraction of supercooled clouds (at the $-20^{\circ} \mathrm{C}$ isotherm) and the coincident dust aerosol frequency are negatively correlated on the planetary scale, due to glaciation by dust (Choi et al., 2010). In the Amazon forest, IN were almost entirely composed of local biological aerosols and some imported Saharan dust (Prenni et al., 2009).

The iron chemistry is important as it can directly affect the radiative budget and the marine ecosystem productivity (Claquin et al., 1999; Sokolik and Toon, 1999; Meskhidze et al., 2005; Luo et al., 2005; Fan et al., 2006; Balkanski et al., 2007). More recently, titanium oxide $\left(\mathrm{TiO}_{2}\right)$ has gained in importance in photochemically induced heterogeneous chemistry reactions. As an example, Ndour et al. (2008) showed that under a UV flux, representative in intensity for atmospheric conditions, $\mathrm{NO}_{2}$ was uptaken at the surface of $\mathrm{TiO}_{2}$-containing dust and leads to the production of HONO.

Many modelling studies point to the uncertainties which still exist in the knowledge of the physico-chemical 
Table 1. Definition of the dust physico-chemical properties and their role in climatic and environmental impact.

\begin{tabular}{llll}
\hline Parameter & Direct radiative effect & Indirect effect & Biogeochemical impact \\
\hline Size distribution & $\begin{array}{l}\text { Optical efficiency } \\
\text { (number size distribution) }\end{array}$ & $\begin{array}{l}\text { CCN/IN activation } \\
\text { (number size distribution) }\end{array}$ & $\begin{array}{l}\text { Wet and dry deposition } \\
\text { (mass size distribution) }\end{array}$ \\
\hline Composition & $\begin{array}{l}\text { Refractive index (mineralogical } \\
\text { and elemental composition) }\end{array}$ & $\begin{array}{l}\text { Hygroscopicity (soluble fraction } \\
\text { and elemental composition) }\end{array}$ & $\begin{array}{l}\text { Wet and dry deposition (soluble fraction } \\
\text { and elemental composition) }\end{array}$ \\
\hline Shape & $\begin{array}{l}\text { Scattering phase function } \\
\text { (aspect ratio, surface roughness) }\end{array}$ & & $\begin{array}{l}\text { Dry deposition } \\
\text { (aspect ratio) }\end{array}$ \\
\hline
\end{tabular}

properties of mineral dust, as a limiting factor in estimating their climatic impact (Claquin et al., 1998; Myhre and Stordal, 2001; Sokolik et al., 2001; Balkanski et al., 2007; Nousiainen, 2009). Besides inherent limitations in the in-situ and remote sensing instrumentation, the description of the physico-chemical properties in chemistry and climate models suffer from a lack of understanding of the processes underlying the dust emission and evolution in the atmosphere.

In this paper, we present a review of the current state of knowledge of the physico-chemical properties of mineral dust relevant to estimating its main impacts. The paper reports on the scientific discussion which has taken place within the Third International Dust Workshop, held in Leipzig (Germany) in September 2008, and it is based on the results of the many field experiments which, in the last decade, have been dedicated to mineral dust: ACE-2 (Raes et al., 2000b), SHADE (Tanré et al., 2003), PRIDE (Reid and Maring, 2003), MINATROC (Balkanski et al., 2003), ADEC (Mikami et al., 2005), ACE-Asia (Huebert et al., 2003), BODEX (Todd et al., 2008); AMMA (Redelsperger et al., 2006), DABEX (Osborne et al., 2008), DODO (McConnell et al., 2008), GERBILS (Haywood et al., 2011), and SAMUM-1 (Heintzenberg, 2009). Acronyms are explained in Appendix A. The need for focused regional closure experiments was highlighted by Sokolik et al. (2001) in the summary of conclusions of the First International Dust Workshop, held in Boulder in 1999.

The aim of this paper is twofold. First, a synthesis of field observations available in the literature is attempted. This cannot be achieved without a critical assessment of the various experimental and analytical methods. Second, this paper tries to identify remaining gaps and priorities for future research.

By doing so, this paper also completes the recently published review by Redmond et al. (2010) on the physical basis, the instrumental techniques, and most recent observation of the optical properties of scattering and absorption by mineral dust.

\section{Sampling and analytical techniques for the study of the physico-chemical properties of mineral dust}

Three principal limitations have to be kept in mind when comparing literature data on physico-chemical parameters of mineral dust. First, most of the data found in the literature represent background to dust emission events (concentrations up to $1000 \mu \mathrm{g} \mathrm{m}^{-3}$ ). Dust storm conditions are rarely investigated, because (a) the source regions are often very remote and hard to access, (b) aircraft sampling is prevented by reduced visibility during high dust conditions, and (c) state of the art instrumentation saturates and may be easily damaged by the extreme atmospheric conditions. An illustration of these difficulties is given by Todd et al. (2008) reporting on the setting up of the BODEX experiment downwind the Bodélé depression in northern Chad. Another difficulty when sampling mineral dust is related to the episodic character of the emission (Laurent et al., 2008).

Second, a major problem of mineral dust sampling in field measurements is the wide size range, in particular the sampling of supermicron particles which constituted the larger fraction of the mass (Pye, 1987). In ground-based studies, measurements are performed downstream inlet systems with certified cut-off diameters as small as $2.5 \mu \mathrm{m}$ or $10 \mu \mathrm{m}$, or with uncertified Total Suspended Particulate (TSP) samplers (Reid et al., 2008; Kandler et al., 2009). Wind-oriented highvolume inlets with high transmission efficiencies are started being used (Rajot et al., 2008; von der Weiden et al., 2009). Recently, dedicated inlet systems for aircraft sampling were developed to improve the even more critical sampling at high air speeds (Wendisch et al., 2004), e.g. the CARIBIC inlet (Hermann et al., 2001), the Big Particles Sampler (Levin et al., 2005), a shrouded inlet system (Dhaniyala et al., 2003), or the PELTI (Huebert et al., 2004).

Third, the available bulk and size-segregated sampling methods are based on different aerosol properties (e.g., optical, inertial, electrical), which depend on composition, shape and size. As a consequence, a meaningful comparison of measurements by techniques based on different principles (e.g., number size distribution measurements by optical and aerodynamical methods) requires the knowledge of additional physico-chemical properties (e.g., composition, particle density and shape; see Hinds (1999). When these 
properties are not measured in parallel, assumptions have to be made to reconcile their measurements.

\subsection{Measuring techniques to assess size distribution}

The number size distribution of airborne dust particles in the full diameter range from approximately $100 \mathrm{~nm}$ to $100 \mu \mathrm{m}$ can be determined by optical methods such as light scattering techniques or imaging techniques such as electron microscopy.

Light scattering techniques measure the optical equivalent diameter referring to a sphere of given refractive index, which scatters the same amount of radiation into a given solid angle and which has the same volume as the dust particle. The composite refractive index of dust particles is determined from chemical composition analyses combined with appropriate mixing rules (Wang et al., 2002; Lafon et al., 2006; Kandler et al., 2007, 2009) or by a combined analysis of optical and microphysical data (Osborne et al., 2008; Petzold et al., 2009). Particle non-sphericity may cause deviations $<10 \%$ for dust particles $>1 \mu \mathrm{m}$ by optical particle counters which measure light scattered in the forward to sideward regime (Osborne et al., 2008). The ratio of nonspherical to spherical particle scattering phase functions is 1.1 for optical particle counters measuring predominately forward-scattered light (Collins et al., 2000), resulting in a slight oversizing if particle sphericity is assumed in the data analysis. Considering realistic dust particle shapes, the deviation of the scattering phase function from that of spheres may increase up to $20 \%$ (Reid et al., 2003a). Furthermore, light scattering methods suffer from a limited size resolution at larger diameters due to the fact that the instruments response for super-micron particles is relatively flat, so that uncertainties in particle refractive index and shape may introduce large errors.

Geometric sizing methods are based on particle collection by filtration or impaction followed by individual particle characterization by transmission (TEM) and/or scanning electron microscopy (SEM) (Baron and Willeke, 2001). Individual particle analysis measures properties like the twodimensional projection area, the volume to surface ratio (Sauter mean diameter) or the gyration diameter, with uncertainties due to pixel resolution, counting statistics, mass losses due to volatility or water evaporation during analysis under high vacuum (Baron and Willeke, 2001; Kandler et al., 2009). This approach also reduces the difficulty in relating the number and the mass size distribution.

Electrical and inertia-based measurements can be used to determine different fractions of the number size distribution. Both methods avoid uncertainties related to assumptions of a distinct particle shape and of an effective complex refractive index. The submicron fraction can be sized in terms of the electrical mobility diameter of a charged particle moving in a static electric field, as done by Differential Mobility Sizer (DMA) or Differential Mobility Particle Sizer (DMPS) methods, respectively. The application of these methods is usually limited to the sub-micron diameter range. Therefore, DMA methods are used in combination with optical particle counters (e.g., de Reus et al., 2000; Clarke et al., 2001; Haywood et al., 2003a; Weinzierl et al., 2009) or with aerodynamic particle sizers (APS; e.g., Wang et al., 2002; Maring et al., 2003), measuring the diameter of a sphere of unit density having the same terminal velocity in an accelerated airflow as the irregularly shaped dust particle (Peters, 2006). A detailed analysis of factors influencing the dust size distributions by means of an APS identified uncertainties in the dynamic shape factor, particle density, and inlet transmission efficiency for different particle sizes. The key conclusion is that APS methods tend to undersize dust particles by at least 10-30\% (Reid et al., 2008) even if a dynamic shape factor of 1.10 to 1.25 (Kaaden et al., 2009) is applied. Despite these limitations, APS methods are capable of covering a particle diameter size range from $0.7 \mu \mathrm{m}$ to $20 \mu \mathrm{m}$.

The mass size distribution is measured by multi-stage filtration or impaction sampling coupled with gravimetric or chemical analysis (Ichoku et al., 1999; Formenti et al., 2001a, 2003; Lafon et al., 2006). A combination of the impaction and filtration is also used by streaker sampling (Annegarn et al., 1996). Uncertainties are due to the efficiency of size-separation, due to particles rebound and shattering and accuracy in flow rate control (Hinds, 1999). Further, because the overwhelming fraction of the mass is in the super-micron fraction, the upper size limit and the exposure time have to be optimised in order to represent equally all size classes.

Comparing size distributions measured by different approaches requires an agreement on aerosol parameters which describe the dust size distribution adequately. The parameterisation of size distributions by multi-modal logarithmic normal distributions is one potential method, if size-binned information on dust particle size distributions is available. The dust particle mode is then characterised by the geometric mean diameter or count median diameter $\mathrm{CMD}$, respectively, and the respective geometrical standard deviation or GSD, respectively (Haywood et al., 2003a; Weinzierl et al., 2009) or by the volume median diameter VMD and the respective geometrical standard deviation GSD (Reid et al., 2008). Whenever possible, a careful analysis of reported equivalent diameters was performed for the determination of reliable particle size distributions by different methods.

Since there is no "true" particle size distribution available, the accuracy of the collected data has to be evaluated carefully. One potential approach is the extinction closure, i.e., the extinction coefficient calculated from the size distribution is compared to a direct measurement of the extinction, e.g. by high spectral resolution lidar (Esselborn et al., 2009). If close agreement between both methods is achieved, then the methods used for the determination of the size distribution and the methods used for the calculation of the extinction coefficient are applicable. If the values disagree, then at least one of the two steps (size distribution measurement, 
extinction coefficient calculation) is not appropriate.

Examples of successful and unsuccessful closure studies are reported in Esselborn et al. (2009), Collins et al. (2000) and Wang et al. (2002). The synthesis of those studies indicates that the representation of the number size distribution over the full size range allows agreement within $15 \%$ between measured and calculated extinction (Esselborn et al., 2009), whereas undersizing of mineral induces discrepancies larger than $35 \%$ (Collins et al., 2000; Wang et al., 2002). The sphericity assumption does not cause a significant deviation from direct extinction measurements can be related to the fact that particle non-sphericity is mostly important for the aerosol backscatter regime (Lacis and Mishchenko, 1995; Mishchenko et al., 1997).

Another approach investigates the discrepancies in measurements of light extinction and extinction-to-backsatter ratio (lidar ratio) of desert dust with CALIPSO and a groundbased Raman lidar system (Wandinger et al., 2010). The underestimation of dust extinction by CALIPSO by $30 \%$ is explained by the influence of multiple scattering which is ignored in the CALIPSO retrievals.

Another potential method for data quality assurance is the mass closure, i.e., the mass concentration calculated from size distributions assuming spherical particles of mineral dust is compared to direct mass concentration measurements by gravimetry. This approach however suffers from the fact that dust particles are highly irregularly shaped. Furthermore, this method is applicable only for ground-based measurements because there are no reliable methods available for airborne measurement of particle mass concentrations.

Summarising the instrument intercomparison studies of the particle size distribution, in situ size distributions can be measured in a reliable manner by optical methods if several requirements are fulfilled: Each instrument requires individual calibration for a precise determination of the instrument response. The complex refractive index has to be known in detail for the inversion of OPC data; instrument response requires adjustment to the respective refractive index value. The effect of particle non-sphericity on particle sizing by light scattering methods has to be evaluated for each instrument individually according to the specific optical set-up of the respective instrument.

\subsection{Measuring techniques to determine particle shape}

The shape of atmospheric mineral dust is assessed mainly by two methods, microscopy and aerodynamic measurements. Only few aerodynamic shape measurements exist for ambient mineral dust (Kaaden et al., 2009). More data sets are available from microscopy measurements, where the size range of atmospheric importance is covered by electron microscopy techniques like transmission and scanning electron microscopy (TEM/SEM). Atomic force microscopy (AFM) is also used, but limited to particles smaller than $1.5 \mu \mathrm{m}$ in diameter (Gwaze et al., 2007; Chou et al., 2008; Helas and Andreae, 2008).

The particle shape obtained by microscopic techniques is usually derived from the two-dimensional outline of the particle. It is mainly expressed as aspect ratio (ratio between longer and shorter axis of an ellipse fitted to the particle outline) or as circularity (ratio of $4 \pi$ times the particle area to the square of the particle perimeter) (Kandler et al., 2007, 2009). While the aspect ratio is a rather robust measure, the circularity is quickly affected by imaging defects and pixel resolution (Podczeck et al., 1999; Almeida-Prieto et al., 2007). For this reason the circularity is less suitable for a comparison. Finally, also fractal dimension is used as measure for dust shape (Koren et al., 2001).

Besides common measurement errors (e.g., sizing, aliasing effects, instrumental artefacts), some principal limitations apply for the shape measurement. Commonly, a strong simplification of the shape is performed, usually to an equivalent (in volume or in area) ellipse or spheroid. While this limitation is not inherent to the microscopical techniques, shapes are usually given in simplified form to serve as base data for optical calculations (e.g., Kandler et al., 2007). Measurements of shape by microscopy are usually performed two-dimensionally (e.g., Reid et al., 2003b; Kandler et al., 2007) with few exceptions (e.g., Okada et al., 2001), and assumptions are made about the third dimension, which may depend on the method of sampling.

Surface roughness affects the scattering phase function especially for particles larger than the wavelength (Nousiainen and Muinonen, 2007). However, only single measurements of surface roughness by atomic force microscopy are available for soil material (Helas and Andreae, 2008) and airborne dust (Chou et al., 2008), but no systematic studies suitable for modelling purposes have been performed yet.

\subsection{Measuring techniques to determine particle composition}

As shown in Table 1, mineral aerosol composition refers to the analysis of different elements depending upon the characteristics of the aerosol and its impact one is trying to assess. Different techniques can be used to highlight these different aspects of mineral aerosol composition.

The major mineral phases of dust (abundance $>5 \%$ by mass) can be identified by X-ray diffraction (XRD) commonly used in soil science (e.g., Schütz and Sebert, 1987; Caquineau et al., 1998; Kandler et al., 2009). Owing to its elevated detection limits, the application of XRD to aerosol samples is however limited to loaded samples of mass higher than $800 \mu \mathrm{g}$ of dust (Caquineau, 1997). Even at high concentrations reached for haze conditions $\left(\sim 1000 \mu \mathrm{g} \mathrm{m}^{-3}\right)$, this detection limit can only be achieved by high-volume sampling and relatively long exposure duration which might only 
be rarely achieved by aircraft sampling (Formenti et al., 2008).

The XRD technique is regarded as a semi-quantitative method due to the difficulty in finding appropriate mineral standards for calibration (Moore and Reynolds, 1997; Caquineau et al., 2002). This is true in particular for clay minerals, whose chemical composition in the aerosol phase can depend on environmental conditions such as weathering.

An alternative to the mineralogy, the elemental composition (frequently expressed as elemental ratios) is often used to characterize the dust composition (e.g., Chiapello et al., 1995). Elemental concentrations can be determined by Xray fluorescence spectrometry (XRF), particle induced X-ray emission (PIXE), or instrumental neutron activation analysis (INAA) (Formenti et al., 2003, 2008; Reid et al., 2003b; Rajot et al., 2008; Zhang et al., 2009; Paris et al., 2010; Müller et al., 2010). These techniques have excellent detection limits for major mineral tracers (lower than $10 \mathrm{ng} \mathrm{cm}^{-2}$ for elements from $\mathrm{Al}$ to $\mathrm{Fe}$ ), allowing analysis of samples with low mass concentration. The well-known X-ray selfattenuation in supermicron particle grains affecting the accuracy of measured light-element concentrations by XRF and PIXE is corrected by using appropriate geological standards, empirical corrections or the complementary use of INAA (Cornille et al., 1990; Formenti et al., 2008, 2010). The dust chemical composition is also determined by inductively coupled plasma atomic emission spectroscopy/mass spectrometry (ICP-AES/ICP-MS) or atomic absorption spectroscopy after acid digestion using hydrofluoric acid (HF) in order to destroy the aluminosilicate matrix (Guieu et al., 2002b; Stuut et al., 2005; Castillo et al., 2008; Lazaro et al., 2008; Jiménez-Vélez et al., 2009). However, HF attacks silicon dioxide to produce soluble silicon tetrafluoride $\left(\mathrm{SiF}_{4}\right)$ in the gaseous phase, preventing the determination of Si concentrations (Pekney and Davidson, 2005).

In order to estimate the fraction of salt minerals in the mineralogical composition of dust samples, or to assess the potential processing of dust by adsorbed gases, the ionic inorganic and organic species (e.g., $\mathrm{NH}_{4}^{+}, \mathrm{NO}_{3}^{-}, \mathrm{SO}_{4}^{2-}, \mathrm{Cl}^{-}$, formate, acetate, oxalate...) are determined by water extraction. Water extraction by sonication is usually used. However, possible artefacts could be produced by sonication since during implosion of the cavitational bubble nitrites and nitrates could form (Koda et al., 2004). The abundance of watersoluble ions is generally measured by ion chromatography (IC) (Formenti et al., 2003; Paris et al., 2010; Müller et al., 2010). The detection limits are low on the order of $\mathrm{ng} \mathrm{m}^{-3}$ for ionic species, corresponding to about $20 \mu \mathrm{g} \mathrm{m}^{-3}$ of dust, or even less in case of mixing during transport (Müller et al., 2010).

Because of its important role in determining the effect of mineral dust on the radiative budget and the marine ecosystem productivity, many recent compositional studies have focussed on the characterisation of iron. Iron occurs mostly in the +3 valence state (i.e., ferric iron), either as Fe(III) ox- ides/hydroxides (hematite or goethite) or as Fe(III) contained in aluminosilicates (e.g., illite and smectite).

Quantification and speciation of iron in dust is achieved by a variety of techniques. An adaptation of the classical soil science selective method of Mehra and Jackson (1960) has been developed by Lafon et al. (2004) to quantify the iron oxide content in samples of mass lower than $500 \mu \mathrm{g}$. The speciation of iron oxides/hydroxides can be achieved by diffuse reflectance in the UV-visible (Arimoto et al., 2002) and high-field isothermal remanence (HIRM) (Hatfield and Maher, 2008), or by a combination of both (Lazaro et al., 2008). Synchrotron-based X-ray absorption spectroscopy (XAS) (Ohta et al., 2006; Schroth et al., 2009) and Mössbauer spectrometry (Hoffmann et al., 1996; Zhang, 2003) are also used to quantify the Fe oxidation state and bonding environment. The characterisation of iron in dust samples can be also obtained by sequential leaching (Chester et al., 1989). This method is particularly interesting for the biogeochemical impact of dust since it provides information on its environmental mobility.

Isotopic composition was used in several papers as source marker. $\mathrm{Sr}, \mathrm{Nd}$ and $\mathrm{Pb}$ radiogenic isotopes, which depend both on the lithology and on the age of the parent rocks from which dust derived, have proved to be the most discriminating array of tracers (Grousset and Biscaye, 2005). A strong grain-size dependence of the different isotope systems (in particular, the ${ }^{87} \mathrm{Sr} /{ }^{86} \mathrm{Sr}$ isotope ratio) has to be taken into account when comparing isotope data from different dust samples (Grousset and Biscaye, 2005; Chen et al., 2007).

The composition of mineral dust can be also measured by single particle techniques. Scanning and transmission electron microscopy (SEM/TEM) combined with energydispersive X-ray microanalysis (EDX) is the most commonly used method for this purpose. Analysis of the chemical composition is practically limited to elements with an atomic number $\geq 4(\mathrm{Be})$, and is restricted to concentrations above approximately 0.1 to $0.5 \%$ wt. Quantification of the element concentrations is complicated by the fact that the particle geometry has to be taken into account in the correction procedures (e.g., Armstrong, 1991). Although algorithms for correction of particle effects are available for automated analysis (e.g., Weinbruch et al., 1997; Ro et al., 2005), in most papers on mineral dust the chemical composition is not determined quantitatively (e.g., Falkovich et al., 2001; Reid et al., 2003b; Zhang et al., 2006; Kandler et al., 2007; Jeong, 2008; Matsuki et al., 2010a), but instead, the net count rates or matrixcorrected data (without geometry correction) are used to categorize the particles into several groups with similar properties (e.g., chemical composition, refractive index), as for example silicates, carbonates, iron oxides. The recent development of automated recognition procedures enable characterization of large particle numbers (30000 to 250000 particles; e.g., Reid et al., 2003b; Kandler et al., 2007, 2009). 
Additional single particle techniques that were applied to mineral dust include laser microprobe mass spectrometry (LMMS), micro particle induced X-ray Emission (micro-PIXE) and aerosol time-of-flight mass spectrometry (ATOFMS). The latter technique is especially powerful as in addition to the elemental composition organic species can be also determined on individual particles (Sullivan et al., 2007b).

Finally, Helas and Andreae (2008) report on the use of AFM and electrostatic force microscopy (EFM) to investigate deposits of distinguishable material on the surface of mineral dust particles.

\section{Physico-chemical properties of African and Asian mineral dust}

The previous discussion illustrates the fact that a synergy of experimental and analytical techniques is necessary in representing the physico-chemical properties of mineral dust. The use of these techniques has proven to be indispensable to investigate specific aspects such as the regional variability at the source and the evolution after transport.

A synthesis of these investigations concerning the African and Asian sources is reported in the following paragraphs.

The Saharan desert and its margins are the largest source of mineral dust on earth, supplying up to $800 \mathrm{Mt}$ per year of material to the atmosphere (Goudie and Middleton, 2001; Laurent et al., 2008). A compilation of the available data on source areas reveals the major potential source areas (PSA; Figs. 1, 2). Dust emission hot spots can be identified using visibility data, back trajectory analysis, satellite observations and isotopic composition studies (e.g., Caquineau et al., 2002; Prospero et al., 2002; Israelevich et al., 2002; Brooks and Legrand, 2003; Goudie, 2003; Chen et al., 2007; Schepanski et al., 2009). The large Saharan sand seas are no prominent sources, as they do not produce mineral dust that can be transported over long distances due to their grain size distribution. The PSA NAF-1 to NAF-6 shown in Fig. 1 are mainly topographical lows and foothills of mountains.

African sources can be fairly well discriminated by combining isotopic ratios ${ }^{87} \mathrm{Sr} /{ }^{86} \mathrm{Sr}$ and $\varepsilon_{\mathrm{Nd}}(0)$ data of soil samples (Table 2a). For example, whereas the highest ${ }^{87} \mathrm{Sr} /{ }^{86} \mathrm{Sr}$ values and least radiogenic $\varepsilon_{\mathrm{Nd}}(0)$ values were reported for north-western areas (PSA NAF-2), PSA NAF-6 (Egypt, Sudan) is characterized by low ${ }^{87} \mathrm{Sr} /{ }^{86} \mathrm{Sr}$ values and significantly higher $\varepsilon_{\mathrm{Nd}}(0)$ values (Grousset et al., 1998; Grousset and Biscaye, 2005).

The Chinese and Mongolian deserts are the second largest global atmospheric dust source. Annual emissions vary between $100 \mathrm{Mt} \mathrm{yr}^{-1}$ and $460 \mathrm{Mt} \mathrm{yr}^{-1}$ (Laurent et al., 2006). This region is a complex and inhomogeneous dust production area with different types of single sources that show distinct properties like soil texture, mineralogical composition, aggregation and crusting all affecting the source strength. Six

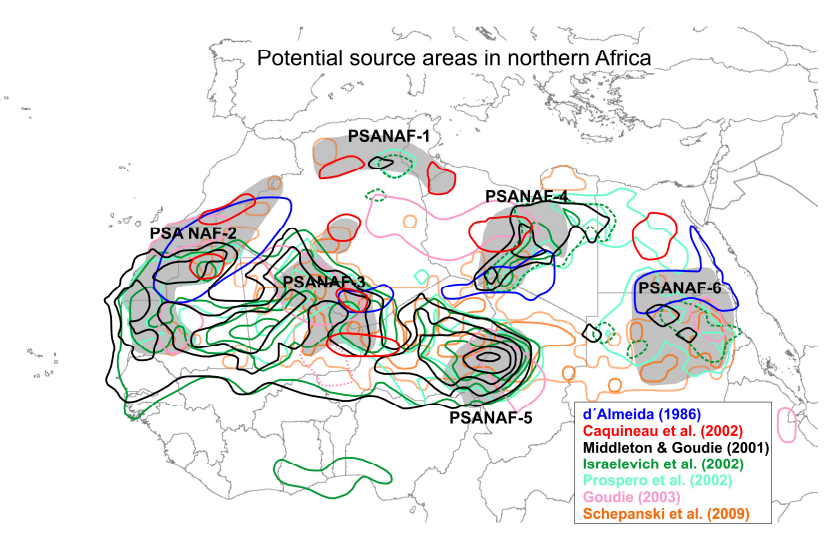

Fig. 1. Potential source areas in Northern Africa (PSA NAF) based on work by Brooks and Legrand (2000) (not shown), Caquineau et al. (2002), Prospero et al. (2002), Israelevich et al. (2002), Goudie (2003), and Schepanski et al. (2009). Map of fraction of dust source activations (DSA) per day by Schepanski et al. (2009) (Fig. 1 in their paper) were transferred to isolines by hand. Outlines of potential source areas (shaded areas) are also drawn by hand. PSA NAF-1: Zone of chotts in Tunisia and Northern Algeria; PSA NAF2: Foothills of Atlas mountains (PSA NAF-2a) and western coastal region (PSA NAF-2b; Western Sahara, Western Mauritania); PSA NAF-3: Mali-Algerian border region; PSA NAF-4: Central Libya; PSA NAF-5: Bodélé depression (Western Chad); PSA NAF-6: Southern Egypt, Northern Sudan.

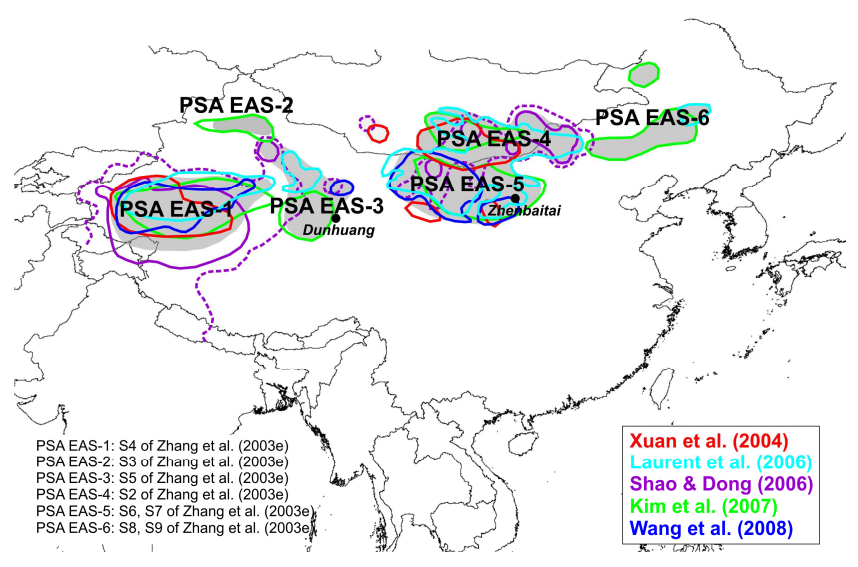

Fig. 2. Potential source areas in Eastern Asia based on work by Xuan et al. (2004), Laurent et al. (2006), Shao and Dong (2006), Kim et al. (2007), Wang et al. (2008), and Zhang et al. (2003e). Outlines of potential source areas (shaded areas) are drawn by hand. PSA EAS-1: Taklamakan; PSA EAS-2: Gurbantunggut; PSA EAS-3: Kumtaq, Qaidam, Hexi corridor; PSA EAS-4: Mongolian (Northern Gobi) deserts; PSA EAS-5: Inner Mongolian (Southern Gobi) deserts: Badain Jaran and Tengger (PSA EAS-5a), Ulan Buh, Hobq, Mu Us (PSA EAS-5b); PSA EAS-6: north-eastern deserts (Otindag Sandy Land, Horquin Sandy Land, Hulun Buir Sandy Land). 
Table 2a. Selected mineralogical (weight $\%)$, elemental $\left(\mu \mathrm{g} \mathrm{m}^{-3} / \mu \mathrm{g} \mathrm{m}^{-3}\right)$, and isotopic parameters for African mineral dusts and source sediments. Note: Chemical analyses given as mass fraction (weight \%) were discarded, because they are very scarce for Asian dusts and are not directly comparable to atmospheric mass concentrations. Note also that carbonate contents were analyzed by different methods (e.g., $\mathrm{XRD}$, titration). For X-ray diffraction analyses carbonate contents are given as the sum of the calcite and dolomite content. The following classification was used for the carbonate content: very low (0-1 wt \%), low (1-10 wt \%), intermediate (10-20 wt \%), high ( $>20 \mathrm{wt} \%)$.

\begin{tabular}{|c|c|c|c|c|c|c|c|c|}
\hline $\begin{array}{l}\text { Potential source } \\
\text { area }\end{array}$ & $\begin{array}{l}\text { Illite/kaolinite } \\
\text { Ratio }\end{array}$ & $\begin{array}{l}\text { Chlorite/ kaolinite } \\
\text { ratio }\end{array}$ & $\begin{array}{l}\text { Carbonate content } \\
\text { (wt \%) }\end{array}$ & $\mathrm{Ca} / \mathrm{Al}$ & $\mathrm{Fe} / \mathrm{Al}$ & $\mathrm{K} / \mathrm{Al}$ & ${ }^{87} \mathrm{Sr} /{ }^{86} \mathrm{Sr}$ & $\epsilon_{\mathrm{Nd}}(0)$ \\
\hline PSA NAF-1 & $\begin{array}{l}\text { 1.0-2.0 } \\
\text { Coudé-Gaussen (1991); } \\
\text { Paquet et al. (1984); } \\
\text { Caquineau et al. (2002) }\end{array}$ & $\begin{array}{l}1.5 \\
\text { Paquet et al. (1984) }\end{array}$ & $\begin{array}{l}10-50 \\
\text { Paquet et al. (1984); } \\
\text { Coudé-Gaussen (1991) }\end{array}$ & - & $\begin{array}{l}0.43-0.70 \\
\text { Chester et al. (1984), } \\
\text { Bergametti et al. (1989b) }\end{array}$ & - & $\begin{array}{l}0.714-0.717 \\
\text { Grousset et al. (1992); } \\
\text { Grousset et al. (1998) }\end{array}$ & $\begin{array}{l}-13.5 \text { to }-9.5 \\
\text { Grousset et al. (1992); } \\
\text { Grousset and Bis- } \\
\text { caye (2005) }\end{array}$ \\
\hline PSA NAF-2 & $\begin{array}{l}>1.6 \\
\text { Avila et al. (1997); } \\
\text { Caquineau et al. (2002); } \\
\text { Kandler et al. (2009) }\end{array}$ & $\begin{array}{l}0.0-0.8 \\
\text { Glaccum and Pros- } \\
\text { pero (1980); Avila et } \\
\text { al. (1997); Kandler et } \\
\text { al. (2009) }\end{array}$ & $\begin{array}{l}\text { 5-70 } \\
\text { Avila et al. (1997); } \\
\text { Khiri et al. (2004); Kan- } \\
\text { dler et al. (2009) }\end{array}$ & $\begin{array}{l}0.60-0.92 \\
\text { Bergametti et al. }(1989 \mathrm{a}) \text {; } \\
\text { Chiapello et al. }(1997) ; \text { For- } \\
\text { menti et al. }(2003,2008)\end{array}$ & $\begin{array}{l}0.54-1.24 \\
\text { Bergametti et al. }(1989 \mathrm{a}, \mathrm{b}) \text {; } \\
\text { Chiapello et al. (1997); For- } \\
\text { menti et al. }(2003,2008)\end{array}$ & $\begin{array}{l}0.1-0.3 \\
\text { Bergametti et al. }(1989 \mathrm{a}) \text {; } \\
\text { Chiapello et al. }(1997) ; \text { For- } \\
\text { menti et al. }(2003,2008)\end{array}$ & $\begin{array}{l}0.720-0.738 \\
\text { Grousset et al. (1992, } \\
1998)\end{array}$ & $\begin{array}{l}-17.9 \text { to }-13.5 \\
\text { Grousset et al. (1998) }\end{array}$ \\
\hline PSA NAF-3 & $\begin{array}{l}0.3-0.7 \\
\text { Paquet et al. (1984); } \\
\text { Caquineau et al. (1998, } \\
\text { 2002) }\end{array}$ & $\begin{array}{l}0.2-0.9 \\
\text { Paquet et al. (1984); } \\
\text { Alastuey et al. (2005) }\end{array}$ & $\begin{array}{l}0-55 \\
\text { Paquet et al. (1984); } \\
\text { Falkovich et al. (2001); } \\
\text { Alastuey et al. (2005) }\end{array}$ & $\begin{array}{l}0.36-0.40 \\
\text { Chiapello et al. (1997); } \\
\text { Alastuey et al. (2005) }\end{array}$ & $\begin{array}{l}0.45-1.69 \\
\text { Bergametti et al. (1989b); } \\
\text { Chiapello et al. (1997); } \\
\text { Alastuey et al. (2005) }\end{array}$ & $\begin{array}{l}0.22 \\
\text { Chiapello et al. (1997); } \\
\text { Alastuey et al. (2005) }\end{array}$ & $\begin{array}{l}(0.721-0.726) \\
\text { Grousset et al. (1998) }\end{array}$ & $\begin{array}{l}-12.4 \text { to }-12.1 \\
\text { Grousset et al. (1998) }\end{array}$ \\
\hline PSA NAF-4 & $\begin{array}{l}0.2-1.9 \\
\text { O'Hara et al. (2006) }\end{array}$ & $\begin{array}{l}0.0-2.6 \text { (occasionally } \\
\text { higher) } \\
\text { O'Hara et al. (2006) }\end{array}$ & $\begin{array}{l}1-25 \\
\text { O'Hara et al. (2006) }\end{array}$ & - & $\begin{array}{l}0.55-0.65 \\
\text { Guieu et al. (2002a) }\end{array}$ & - & $\begin{array}{l}0.715 \\
\text { Grousset and Bis- } \\
\text { caye }(2005)\end{array}$ & $\begin{array}{l}-15.4 \text { to }-10.7 \\
\text { Grousset and Bis- } \\
\text { caye }(2005)\end{array}$ \\
\hline PSA NAF-5 & $\begin{array}{l}0.0-0.4 \\
\text { Mounkaila (2006) }\end{array}$ & $\begin{array}{l}\text { chlorite not detected } \\
\text { Mounkaila (2006) }\end{array}$ & $\begin{array}{l}\text { mainly very low } \\
\text { Mounkaila (2006) }\end{array}$ & $\begin{array}{l}0.4 \\
\text { Formenti et al. (2008) }\end{array}$ & $\begin{array}{l}0.6 \\
\text { Formenti et al. (2008) }\end{array}$ & $\begin{array}{l}0.3 \\
\text { Formenti et al. (2008) }\end{array}$ & - & $\begin{array}{l}-12.7 \\
\text { Grousset and Bis- } \\
\text { caye (2005) }\end{array}$ \\
\hline PSA NAF-6 & $\begin{array}{l}0.7 \\
\text { Caquineau et al. (2002) }\end{array}$ & - & - & $\begin{array}{l}0.75 \\
\text { Eltayeb et al. (1993) }\end{array}$ & $\begin{array}{l}1.08 \\
\text { Eltayeb et al. (1993) }\end{array}$ & $\begin{array}{l}0.24 \\
\text { Eltayeb et al. (1993) }\end{array}$ & $\begin{array}{l}0.716-0.718 \\
\text { Grousset and Bis- } \\
\text { caye }(2005)\end{array}$ & $\begin{array}{l}-11.0 \text { to }-3.9 \\
\text { Grousset and Bis- } \\
\text { caye (2005) }\end{array}$ \\
\hline
\end{tabular}

Table 2b. Selected mineralogical (weight $\%$ ), elemental $\left(\mu \mathrm{g} \mathrm{m}^{-3} / \mu \mathrm{g} \mathrm{m} \mathrm{m}^{-3}\right.$ ), and isotopic parameters for Asian mineral dusts and source sediments. Note: Chemical analyses given as mass fraction (weight \%) were discarded, because they are very scarce for Asian dusts and are not directly comparable to atmospheric mass concentrations. Note also that carbonate contents were analyzed by different methods (e.g., $\mathrm{XRD}$, titration). For X-ray diffraction analyses carbonate contents are given as the sum of the calcite and dolomite content. The following classification was used for the carbonate content: very low (0-1 wt \%), low (1-10 wt \%), intermediate (10-20 wt \%), high ( $>20 \mathrm{wt} \%)$.

\begin{tabular}{|c|c|c|c|c|c|c|c|c|}
\hline $\begin{array}{l}\text { Potential source } \\
\text { area }\end{array}$ & $\begin{array}{l}\text { Illite/kaolinite } \\
\text { ratio }\end{array}$ & $\begin{array}{l}\text { Chlorite/ kaolinite } \\
\text { ratio }\end{array}$ & $\begin{array}{l}\text { Carbonate content } \\
\text { (wt \%) }\end{array}$ & $\mathrm{Ca} / \mathrm{Al}$ & $\mathrm{Fe} / \mathrm{Al}$ & $\mathrm{K} / \mathrm{Al}$ & ${ }^{87} \mathrm{Sr} /{ }^{86} \mathrm{Sr}$ & $\epsilon_{\mathrm{Nd}}(0)$ \\
\hline PSA EAS-1 & $\begin{array}{l}12.5-13.9 \\
\text { Shen et al. (2005) }\end{array}$ & $\begin{array}{l}3.3 \\
\text { Shen et al. (2005) }\end{array}$ & $\begin{array}{l}6-35 \\
\text { Wang et al. (2005); } \\
\text { Li et al. (2007); } \\
\text { Wang et al. (2008) }\end{array}$ & $\begin{array}{l}2.04-4.14 \\
\text { Zhang et al. (1996); } \\
\text { Zhang et al. (2003d); } \\
\text { Makra et al. (2002) }\end{array}$ & $\begin{array}{l}0.87-1.74 \\
\text { Zhang et al. (1996); } \\
\text { Zhang et al. (2003d); } \\
\text { Makra et al. (2002) }\end{array}$ & $\begin{array}{l}0.54-0.94 \\
\text { Zhang et al. (1996); } \\
\text { Zhang et al. (2003d); } \\
\text { Makra et al. (2002) }\end{array}$ & $\begin{array}{l}0.712-0.721 \\
0.722-0.730(<5 \mu \mathrm{m}) \\
\text { Sun (2002a, b); Bory et al. (2003); } \\
\text { Honda et al. (2004); Nakano et } \\
\text { al. (2004); Kanayama et al. (2005); } \\
\text { Chen et al. (2007) }\end{array}$ & $\begin{array}{l}-12.7 \text { to }-8.4 \\
\text { Bory et al. (2003); Honda et } \\
\text { al. (2004); Nakano et al. (2004); } \\
\text { Kanayama et al. (2005); Chen et } \\
\text { al. (2007) }\end{array}$ \\
\hline PSA EAS-2 & - & - & $\begin{array}{l}0-10 \\
\text { Wang et al. (2005); } \\
\mathrm{Li} \text { et al. (2007); } \\
\text { Wang et al. }(2008)\end{array}$ & $\begin{array}{l}1.69 \\
\text { Zhang et al. (1996) }\end{array}$ & $\begin{array}{l}0.48 \\
\text { Zhang et al. (1996) }\end{array}$ & $\begin{array}{l}0.43 \\
\text { Zhang et al. (1996) }\end{array}$ & $\begin{array}{l}0.711-0.714 \\
0.717(<5 \mu \mathrm{m}) \\
\text { Sun (2002a, b); Honda et al. (2004); } \\
\text { Nakano et al. (2004); Chen et } \\
\text { al. (2007) }\end{array}$ & $\begin{array}{l}-6.3 \text { to }-1.2 \\
\text { Honda et al. (2004); Nakano et } \\
\text { al. (2004); Chen et al. (2007) }\end{array}$ \\
\hline PSA EAS-3 & $\begin{array}{l}7.0-8.0 \\
\text { Shen et al. (2006) }\end{array}$ & $\begin{array}{l}2.0-2.2 \\
\text { Shen et al. (2006) }\end{array}$ & $\begin{array}{l}4-13 \\
\text { Wang et al. (2005); } \\
\text { Shen et al. (2006); } \\
\text { Li et al. (2007); } \\
\text { Wang et al. (2008) }\end{array}$ & $\begin{array}{l}0.94-1.80 \\
\text { Zhang et al. (1996, } \\
2003 \mathrm{c}, \mathrm{d})\end{array}$ & $\begin{array}{l}0.65-3.53 \\
\text { Zhang et al. (1996, } \\
2003 \mathrm{c}, \text { d) }\end{array}$ & $\begin{array}{l}0.26-0.44 \\
\text { Zhang et al. (1996, } \\
2003 \text { c, d) }\end{array}$ & $\begin{array}{l}0.713-0.720 \\
0.723-0.733(<5 \mu \mathrm{m}) \\
\text { Sun (2002b); Nakano et al. (2004); } \\
\text { Kanayama et al. (2005); Chen et } \\
\text { al. (2007) }\end{array}$ & $\begin{array}{l}-13.9 \text { to }-8.8 \\
\text { Nakano et al. (2004); Kanayama et } \\
\text { al. (2005); Chen et al. (2007) }\end{array}$ \\
\hline PSA EAS-4 & $\begin{array}{l}\text { 1.1-6.0 } \\
\text { Biscaye et al. (1997); } \\
\text { Svensson et al. (2000) }\end{array}$ & $\begin{array}{l}\text { 1.3-3.0 } \\
\text { Biscaye et al. (1997); } \\
\text { Svensson et al. (2000) }\end{array}$ & $\begin{array}{l}0-5 \\
\text { Wang et al. (2005); } \\
\text { Jeong (2008) }\end{array}$ & $\begin{array}{l}0.42 \\
\text { Sun et al. (2005) }\end{array}$ & $\begin{array}{l}0.55 \\
\text { Sun et al. (2005) }\end{array}$ & - & $\begin{array}{l}0.713-0.716 \\
0.714-0.719(<5 \mu \mathrm{m}) \\
\text { Biscaye et al. (1997); Bory et } \\
\text { al. (2003); Nakano et al. (2004) }\end{array}$ & $\begin{array}{l}-9.9 \text { to }-4.9 \\
\text { Biscaye et al. (1997); Bory et } \\
\text { al. (2003); Nakano et al. (2004) }\end{array}$ \\
\hline PSA EAS-5 & $\begin{array}{l}5.0-5.6 \\
\text { Shen et al. (2005) }\end{array}$ & $\begin{array}{l}1.4 \\
\text { Shen et al. (2005) }\end{array}$ & $\begin{array}{l}0-10 \\
\text { Wang et al. }(2005) ; \\
\mathrm{Li} \text { et al. (2007); } \\
\text { Jeong }(2008) ; \\
\text { Wang et al. }(2008)\end{array}$ & $\begin{array}{l}0.67-2.43 \\
\text { Zhang et al. (1996); } \\
\text { Alfaro et al. (2003); } \\
\text { Zhang et al. (2003c, d); } \\
\text { Arimoto et al. (2004); } \\
\text { Xu et al. (2004); Sun et } \\
\text { al. (2005) }\end{array}$ & $\begin{array}{l}0.36-1.60 \\
\text { Zhang et al. (1996); } \\
\text { Alfaro et al. (2003); } \\
\text { Zhang et al. (2003c, d); } \\
\text { Arimoto et al. (2004); } \\
\text { Xu et al. (2004); Sun et } \\
\text { al. (2005) }\end{array}$ & $\begin{array}{l}0.20-1.00 \\
\text { Zhang et al. (1996); } \\
\text { Alfaro et al. (2003); } \\
\text { Zhang et al. (2003c, d); } \\
\text { Arimoto et al. (2004); } \\
\text { Xu et al. (2004); Sun et } \\
\text { al. (2005) }\end{array}$ & $\begin{array}{l}0.713-0.726 \\
0.721-0.732(<5 \mu \mathrm{m}) \\
\text { Bory et al. (2003); Honda et } \\
\text { al. (2004); Nakano et al. (2004); } \\
\text { Yokoo et al. (2004); Kanayama et } \\
\text { al. (2005); Chen et al. (2007) }\end{array}$ & $\begin{array}{l}-19.7 \text { to }-7.2 \\
\text { (W-E trend) } \\
\text { Bory et al. (2003); Honda et } \\
\text { al. (2004); Nakano et al. (2004); } \\
\text { Yokoo et al. (2004); Kanayama et } \\
\text { al. (2005); Chen et al. (2007) }\end{array}$ \\
\hline PSA EAS-6 & $\begin{array}{l}7.5-9.7 \\
\text { Shen et al. (2005) }\end{array}$ & $\begin{array}{l}1.7-2.0 \\
\text { Shen et al. (2005) }\end{array}$ & $\begin{array}{l}<1 \\
\text { Wang et al. }(2005) \text {; } \\
\mathrm{Li} \text { et al. (2007); } \\
\text { Jeong et al. (2008) }\end{array}$ & $\begin{array}{l}0.31-0.94 \\
\text { Cheng et al. (2005); } \\
\text { Shen et al. (2007) }\end{array}$ & $\begin{array}{l}0.70-1.07 \\
\text { Cheng et al. (2005); } \\
\text { Shen et al. (2007) }\end{array}$ & $\begin{array}{l}0.36-0.80 \\
\text { Cheng et al. (2005); } \\
\text { Shen et al. (2007) }\end{array}$ & $\begin{array}{l}0.710-0.714 \\
0.716-0.717(<5 \mu \mathrm{m}) \\
\text { Honda et al. (2004); Nakano et } \\
\text { al. (2004); Chen et al. (2007) }\end{array}$ & $\begin{array}{l}-7.9 \text { to }-0.8 \\
\text { Honda et al. (2004); Nakano et } \\
\text { al. (2004); Chen et al. (2007) }\end{array}$ \\
\hline
\end{tabular}

important potential source areas may be identified in Fig. 2 based on a survey of the recent literature (Sun et al., 2001; Prospero et al., 2002; Zhang et al., 2003c; Xuan et al., 2004; Shao and Dong, 2006; Laurent et al., 2006; Chen et al., 2007;
Kim et al., 2007; Li et al., 2007; Sun et al., 2007; Wang et al., 2008; Lee and Sohn, 2009; Yang et al., 2009).

Recently, a large data set for eastern Asia was produced (see Table 2 b), comprising ${ }^{87} \mathrm{Sr} /{ }^{86} \mathrm{Sr}$ and $\varepsilon_{\mathrm{Nd}}(0)$ analyses of 
various size fractions from different potential source areas. Especially on the basis of $\varepsilon_{\mathrm{Nd}}(0)$ values, a clear distinction between areas with low $\varepsilon_{\mathrm{Nd}}(0)$ values (PSA EAS-1, PSA EAS-3, PSA EAS-5) and higher $\varepsilon_{\mathrm{Nd}}(0)$ values (PSA EAS-2, PSA EAS-6) is possible (Yang et al., 2009). It is also remarkable that local trends in single potential source areas can be revealed by isotope composition (e.g., increasing $\varepsilon_{\mathrm{Nd}}(0)$ values from west to east in PSA EAS-5; Chen et al., 2007). Beside these general findings, source discrimination based on chemical composition will not be discussed here.

\subsection{Particle composition}

\subsubsection{Characterisation of the composition of source regions}

Selected mineralogical, elemental, and isotopic parameters of dust from northern Africa and eastern Asia are presented in Tables $2 \mathrm{a}$ and $2 \mathrm{~b}$.

In northern Africa, the calcite (or carbonate) content and the ratio of the clay minerals illite and kaolinite (I/K ratio) can serve as "fingerprints" of specific source areas (e.g., Schütz and Sebert, 1987; Caquineau et al., 2002). The highest $\mathrm{I} / \mathrm{K}$ ratios are observed in mineral dust that originated in north-western source areas (Fig. 1, PSA NAF-1, PSA NAF2). High carbonate contents were reported for the northwestern areas and PSA NAF-3 (southern Algeria/northern Mali). The chlorite content and the chlorite/kaolinite ratio $(\mathrm{C} / \mathrm{K}$ ratio) are generally low and cannot be used for discrimination between different PSA. The Mg-dominated fibrous clay mineral (palygorskite) appears to be a suitable source marker for north-western PSA (PSA NAF-1, PSA NAF-2a) and, to a lesser extent, for PSA NAF-3. Palygorskite is also found in significant amounts in dust emitted from the Arabian Peninsula (Ganor et al., 1991; Kalderon-Asael et al., 2009).

Only a few studies deal with the mineralogical composition of unpolluted aerosol and possible source sediments in China (Svensson et al., 2000; Shen et al., 2005, 2006; Jeong, 2008). Despite the limited data set (in comparison to Northern Africa), major differences between northern Africa and eastern Asia are observed. For example, the $\mathrm{I} / \mathrm{K}$ ratio is generally higher in samples from eastern Asia $(I / K>5)$ than in samples from northern Africa $(\mathrm{I} / \mathrm{K}<2)$, with the one exception of PSA EAS-4 (south-eastern Mongolia). The $\mathrm{C} / \mathrm{K}$ ratio is mostly higher in eastern Asian source regions $(\mathrm{C} / \mathrm{K}>1.5)$, compared to northern Africa $(\mathrm{C} / \mathrm{K}<1.5)$. As all three minerals appear in the same size fraction and have similar densities it can be expected that the $\mathrm{I} / \mathrm{K}$ and $\mathrm{C} / \mathrm{K}$ ratios are not substantially changed during long-range transport. Similar to northern Africa, the $\mathrm{I} / \mathrm{K}$ ratio in eastern Asia seems to be a more effective tool to discriminate between different PSA than the $\mathrm{C} / \mathrm{K}$ ratio. The $\mathrm{I} / \mathrm{K}$ ratios are highest in western source areas (PSA EAS-1) and lowest in northern Gobi deserts (PSA EAS-4). In addition, the carbonate content generally de-

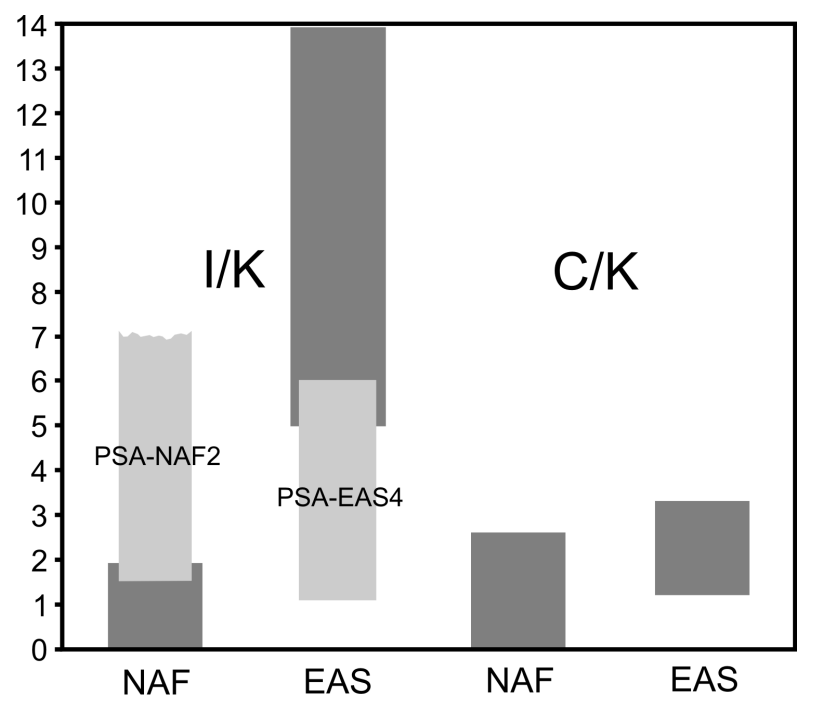

Fig. 3. Range of variability of illite/kaolinite (I/K) and chlorite/kaolinite $(\mathrm{C} / \mathrm{K})$ ratios for North African (NAF) and East Asian (EAS) mineral dust and source sediments. Light grey areas: single potential source areas which show deviations from the general trend (the range of the $\mathrm{I} / \mathrm{K}$ ratios for PSA NAF-2 may extend to higher values).

creases from west to east (with exception of the Gurbantunggut desert (PSA EAS-2), where the carbonate content is very low) and hence can also be used as a compositional fingerprint for the regional provenance of eastern Asian dust. Dolomite $\left(\mathrm{CaMg}\left(\mathrm{CO}_{3}\right)_{2}\right)$ has also been suggested as a possible source tracer for Asian dust (Li et al., 2007), offering the possibility to discriminate between dolomite-bearing dusts originated in PSA EAS1, PSA EAS3, and the western part of PSA EAS5 (Badain Jaran Desert) and dust uplifted in other source regions (e.g., PSA EAS-2, eastern part PSA EAS-3 and PSA EAS-6) without dolomite. For sake of illustration, the range of variability of the $\mathrm{I} / \mathrm{K}$ and $\mathrm{C} / \mathrm{K}$ ratios for dust aerosols and source sediments are also shown in Fig. 3.

Atmospheric concentration ratios for $\mathrm{Ca} / \mathrm{Al}, \mathrm{Fe} / \mathrm{Al}$ and $\mathrm{K} / \mathrm{Al}$ for northern African and eastern Asian dust are also presented in Tables $2 \mathrm{a}$ and $2 \mathrm{~b}$. $\mathrm{Al}$ is chosen as a marker element for alumino-silicates. Ca is mainly a tracer for the carbonate minerals (calcite and dolomite), and to a lesser extent, of sulphates such as gypsum and of Ca-bearing plagioclase. $\mathrm{K}$ is predominantly a component of clay illite and potassic feldspar.

Though the $\mathrm{Si} / \mathrm{Al}$ ratio is often reported, its capability to distinguish source regions is limited due to its low variability around 2.3 (Chiapello et al., 1997; Formenti et al., 2001a, 2003, 2008; Reid et al., 2003b; Rajot et al., 2008). An exception is the Bodélé depression source (PSA NAF-5) which, because of the resuspension of detrital diatoms deposited at the surface after the drought of Mega-Lake Chad (Todd et al., 2008), presents values of $\mathrm{Si} / \mathrm{Al}$ reaching 4 (Formenti et al., 2008). 
The higher $\mathrm{Ca} / \mathrm{Al}$ ratios in the north-west (PSA NAF-2) compared to samples from PSA NAF-3 (Mali-Algerian border region) are probably correlated with the higher carbonate contents in source sediments of the Atlas region (PSA NAF-2).

The $\mathrm{Fe} / \mathrm{Al}$ and $\mathrm{K} / \mathrm{Al}$ ratios show little variability from one source area to the other. However, Kandler et al. (2007) emphasized an opposite north-south gradient of $\mathrm{Fe}$ and $\mathrm{Ca}$ content in dust samples collected at Tenerife (Canary Islands), showing higher $\mathrm{Fe}$ content for dust originating of PSA NAF3. Compared to Africa, eastern Asian dust shows higher $\mathrm{Ca} / \mathrm{Al}$ and $\mathrm{K} / \mathrm{Al}$ ratios, but similar $\mathrm{Fe} / \mathrm{Al}$ ratios (Zhang et al., 2003d; Arimoto et al., 2006). The $\mathrm{Ca} / \mathrm{Al}$ ratio exhibits a geographical dependence with decreasing ratios to the east (see Table 2), following the carbonate distribution in soil. In contrast, the Fe/Al and $\mathrm{K} / \mathrm{Al}$ ratios are more homogeneous, exhibiting only a weak regional trend. It can be concluded that based on the currently available data the $\mathrm{Ca} / \mathrm{Al}$ ratio is the most promising in discriminating mineral dusts of different source areas. However, in potential source areas where a high number of mineralogical or chemical analyses is available, a significant compositional heterogeneity in one source region may be recognized. For example, the data sets of Mounkaila et al. (2006) and Bristow et al. (2010) reveal both a variety in mineralogical and chemical composition for the potential source sediments of the Bodélé depression in Northern Africa. In a few examples, even compositional trends in single source areas may be revealed (e.g., W-E trend of $\varepsilon_{\mathrm{Nd}}(0)$ values in PSA EAS-5 in Eastern Asia).

Most of the last years' research has focuses on iron chemistry, in particular on the partitioning between the structural iron trapped in clay-crystal lattice and the iron oxides/hydroxides in the form of hematite $\left(\mathrm{Fe}_{2} \mathrm{O}_{3}\right)$ and goethite (FeOOH). Iron oxides/hydroxides were also assumed to be a major source of water-soluble iron, i.e., iron which is potentially available for dissolution in sea water. However, it was shown recently (Journet et al., 2008) that more than $96 \%$ of the water-soluble iron is associated with the dissolution of the abundant clay minerals.

In northern African source areas, the iron oxide content, determined by the CBD-extraction method (Lafon et al., 2004 ), ranges from $43 \%$ to $65 \%$ of the elemental iron content ( 2.4 to $5 \%$ of total mass, respectively) with higher values obtained for Sahelian dust emitted locally from Niger and Mauritania in the Sahel belt and lower ones for the Chad basin (Formenti et al., 2008; PSA NAF-5). The iron oxide content of dust transported to the Canary Islands ranges from $27 \%$ to $63 \%$, with the tendency of higher values for source areas between $0^{\circ} \mathrm{N}-20^{\circ} \mathrm{N}$ (Lazaro et al., 2008; PSA NAF3 ). Dust produced in laboratory wind tunnel from Niger and Tunisian soils show that goethite seems to be the most abundant iron species comprising about $65-85 \%$ of the total iron oxide mass (Lafon et al., 2006). However, the results of Lazaro et al. (2008) for different African sources (PSA NAF-1, PSA NAF-2 as well as Mali region) show a hematite/goethite ratio with a large variability between 0.5 and 2. Comparison on the hematite/goethite ratio in dust collected in Asian source areas (PSA EAS-3, PSA EAS-5 and PSA EAS-6) show a low ratio with a slight variability between 0.46 and 0.59 (Shen et al., 2006). Thus, goethite cannot be used for source discrimination for African or Asian dust.

Electron-microscopy observations of African dust show that iron is present as both $\mathrm{Fe}$-containing silicate and as iron oxide grains in and on silicate particles (notably clay minerals). This is observed close to the dust sources (Greenland et al., 1968; Lafon, 2004; Kandler et al., 2007) as well as after transport (Falkovich et al., 2001; Blanco et al., 2003; Reid et al., 2003b; Singer et al., 2004; Kandler et al., 2009). Isolated iron-rich particles are rarely observed (less of $3 \%$ in number of total observed particles) and they are usually small (Kandler et al., 2007, Chou et al., 2008). Similar observations were made for Chinese dust (Iwasaka et al., 2003; Trochkine et al., 2003; Gao et al., 2007). For Asian dust, Ohta et al. (2006) found that the iron concentration is rather constant for particle sizes of $1.1-11.0 \mu \mathrm{m}$, and a variation is observed below $1 \mu \mathrm{m}$, which may be attributed to anthropogenic activities. For example, a lower abundance of iron in the fine fraction is observed by Iwasaka et al. (2003) over the Taklamakan desert. However, the results show no trend of the size-resolved iron distribution in terms of changing source region or distance to the source. Speciation of iron valence state shows that all iron is present as Fe(III) for the size fraction below $11 \mu \mathrm{m}$ and approx. $93 \%$ for the fraction larger than $11 \mu \mathrm{m}$ (Ohta et al., 2006). It is also observed that the ratios of $\mathrm{Fe}(\mathrm{III})$ to total $\mathrm{Fe}$ close to Asian source and after long-range transport are similar, indicating that redox reactions of $\mathrm{Fe}$ in aeolian dust during transport are negligible. These observations are in agreement with results for soil (representative of coarse aerosol mode), where $\mathrm{Fe}(\mathrm{II})$ is usually also low and is contained mainly in aluminosilicates (Ohta et al., 2006; Cwiertny et al., 2008).

\subsubsection{Changes of composition during transport}

In Asia, strong desert sources are located close to polluted areas leading to intense mixing. Thus, many individual particle studies in this region focus on the mixing state and its evolution during transport. Field measurements have shown that many dust particles contain sulphates or nitrates which are formed by heterogeneous reactions involving sulphur dioxide and nitrogen oxides, particularly in the marine atmosphere where the relative humidity is high (Trochkine et al., 2003; Zhang et al., 2003a). Most dust particles take up sulphate in the marine air during transport from the Asian continent to the Japanese islands and, thus, act as a sink for gaseous sulphur (Okada and Kai, 1995, 2004; Fan et al., 1996; Zhou et al., 1996; Trochkine et al., 2003; Zhang et al., 2003a, d). An increase of nitrate-containing Asian dust particles during transport was also described, although it is not as pronounced as for sulphate (Zhang et al., 2003a, c). 
For African dust, the Mediterranean basin is the major zone of transport with high polluted areas. A strong internal mixing of dust and sulphate was also reported for the eastern Mediterranean and Western Africa (e.g., Falkovich et al., 2001; Sobanska et al., 2003; Koçak et al., 2007). The nitrate formation on dust particles has also been observed as a result of the interaction with $\mathrm{HNO}_{3}$ (Putaud et al., 2004; Koçak et al., 2007).

The enrichment of sulphate and nitrate on dust particles in the marine atmosphere is linked to the high humidity. In marine air, it can be expected that dust particles become soon wetted by formation of thin water films on the surface or partial deliquescence (i.e., deliquescence of the soluble fraction contained in agglomerates). The presence of liquid water will result in more efficient transformation of sulphur dioxide to sulphate and nitrogen oxides to nitrate. Nonetheless, the results of Putaud et al. (2004) indicate that nitrate formation on dust particles occurs even when the relative humidity is low.

Formation of sulphate and nitrate is also closely related to the mineral composition. Laboratory experiments and field observations both revealed that sulphate formation is favoured on aluminium silicate particles compared to calcium carbonate (Krueger et al., 2003; Laskin et al., 2005a; Shi et al., 2008). The opposite behaviour is observed for nitrate formation (Ro et al., 2005; Sullivan et al., 2007a; Matsuki et al., 2010a; Fairlie et al., 2010). The preferential nitrate formation on carbonates can be explained by the different hygroscopicity of $\mathrm{Ca}$ nitrate and $\mathrm{Ca}$ sulphate. Calcium sulphate (the reaction product on carbonates) is poorly water soluble preventing further uptake of water and other gaseous species. Consequently, the transformation of sulphur dioxide to sulphate is suppressed in these particles. In contrast, the major product of nitrate formation on carbonate particles is highly hydrophilic (Sullivan et al., 2009). Thus, uptake of water is enhanced resulting in a positive feedback. This feedback process will be operating until all calcium in the particles is transformed to calcium nitrate. The frequent observation of calcium-rich spherical particles in Asian dust plumes in Japan and in polluted urban air masses in China (Matsuki et al., 2005), as well as in the Eastern Mediterranean (Laskin et al., 2005a) is a strong indication for the feedback process outlined above. Calcium-rich spherical particles have also been observed during AMMA campaigns in convective systems over Sahel (Matsuki et al., 2010a) in parallel with a strong internal mixing of dust with nitrate or sulphate suggesting an in-cloud processing (Crumeyrolle et al., 2008; Matsuki et al., 2010b).

A few studies found chloride on sea-salt free dust particles and suggested that the absorption of hydrogen chloride was responsible for the chloride formation. This phenomenon was first observed and its importance with respect to the formation of sulphate evaluated by Zhang and Iwasaka (2001). Recent observations with ATOFMS during ACE-2 at the North Atlantic and ACE-Asia at the Northern Pacific pro- vided more quantitative data to support this finding (Sullivan et al., 2007a, b). A study by Tobo et al. (2009) found that the chloride formation on dust particles was more pronounced in episodes of weak sulphate and nitrate formation, suggesting the presence of an additional process of dust modification by gaseous species. They further showed that elevated concentrations of $\mathrm{HCl}$ in the remote marine boundary layer were sufficient to modify Ca-rich particles and could play a more important role in forming a deliquescent layer on particle surfaces (Tobo et al., 2010). ACE-Asia results emphasize also a possible mixing between dust and organic dicarboxylic acid (DCA), like oxalic and malonic acid, due to heterogeneous and aqueous oxidation of DCA on the surface of the alkaline Asian dust (Sullivan and Prather, 2007). Internal mixing between dust and organic material has also been suggested for African dust in source areas during monsoon periods by incloud process in convective system (Desboeufs et al., 2010) and in zones of transport in Israel (Falkovich et al., 2001) and over the French Alps (Aymoz et al., 2004).

Mixing of dust with particulate matter is expected to include sea salt, soot, and primary biological particles (e.g., microorganisms). The mechanisms responsible for the mixing of dust particles and sea-salt have not been elucidated in detail (Andreae et al., 1986; Zhang et al., 2005). In mineral dust collected at the Japanese islands (i.e. after several hours of transport in the marine air) more than $60 \%$ of the particles were internally mixtures of mineral dust and seasalt (Okada et al., 1990; Niimura et al., 1998; Zhang et al., 2003b). This abundance is much higher than that predicted from particle-to-particle collision theory based on Brownian motion, implying that additional processes assist the mixing (e.g., Ma and Choi, 2007). While in-cloud processing was suggested as a major route for agglomerate formation (Andreae et al., 1986; Niimura et al., 1998), the high abundance of internally mixed particles were observed during cloud-free days. Small-scale phenomena, such as streak flow or warm rolls in the marine boundary layer may change the settling of dust particles to the surface and be responsible for the mixing, however, the exact pathway and the dominating effect is still unclear (Andreae and Rosenfeld, 2008; Zhang, 2008). In contrast, mixtures of dust and sea-salt were reported to occur only to a minor degree in the African dust plume outflow (e.g., Reid et al., 2003b; Niemi et al., 2005; Kandler et al., 2007). In summertime, this is surely due to the fact that dust is mostly transported above the marine boundary layer (Karyampudi et al., 1999). Although subsidence might occur during long-range transport the dust-laden layer is generally well distinct from the marine boundary layer in terms of thermodynamical structure (Reid et al., 2002). In wintertime, additional low-level transport might occur, as documented by Chiapello et al. (1995) at the Sal Island, few hundreds of kilometres far from the Senegal coast. On these occasions, the sea-salt contribution was less than $10 \%$ by mass (Chiapello et al., 1999). 

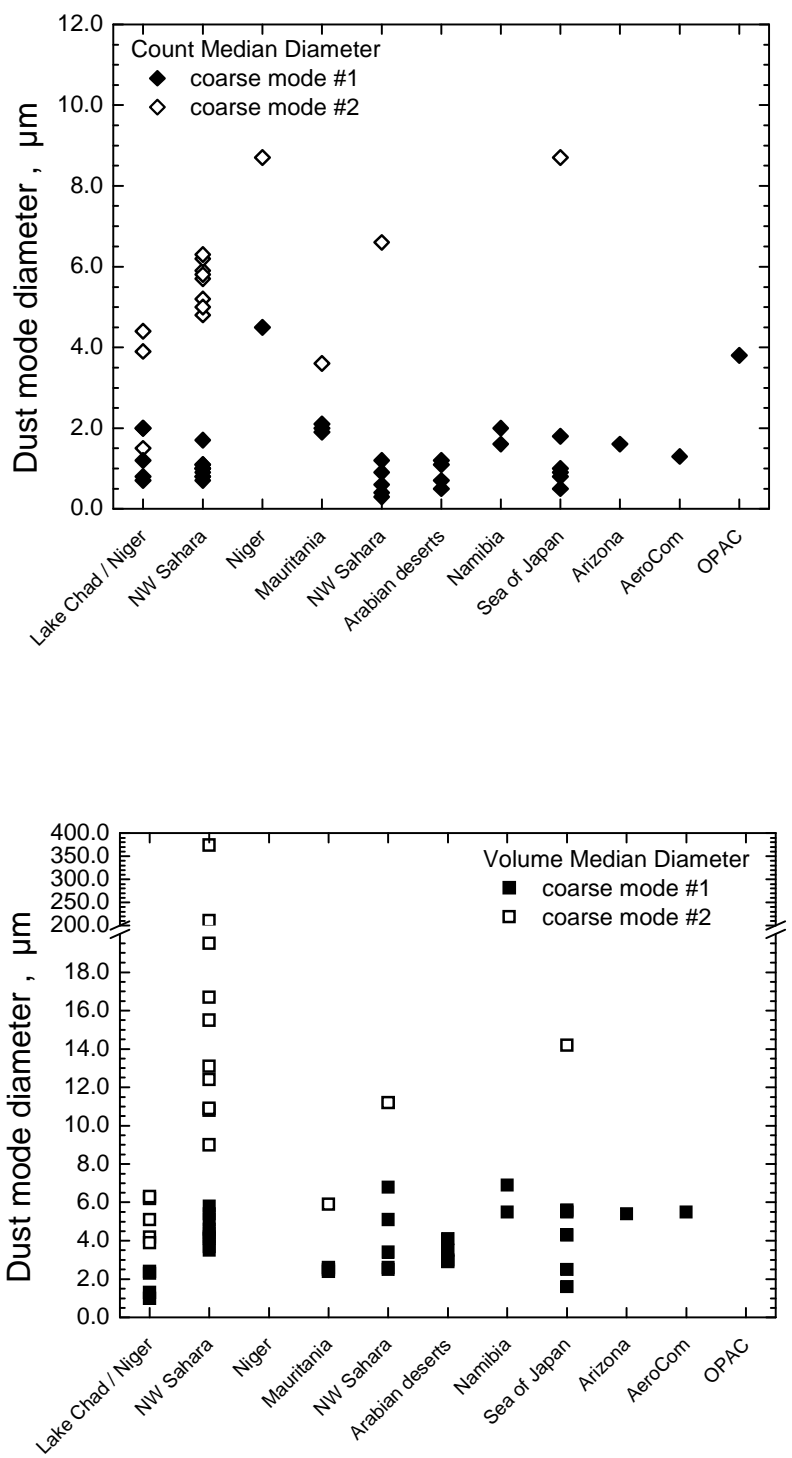

Fig. 4. Count Median Diameter (CMD, upper panel) and Volume Median Diameter (VMD, lower panel) as a function of source region for the dust coarse mode data compilation presented in Table 3. Data issued from model databases (AEROCOM and OPAC) are shown for comparison.

Only few publications show the presence of some internal mixtures of soot and mineral dust in connection with intensive burning processes and high sample loadings (Parungo et al., 1992, 1994; Hand et al., 2010). For other situations, there is no report on internal mixtures of soot and mineral dust, while external mixtures of dust and organic carbon may be more frequent (Falkovich et al., 2004; Kandler et al., 2009; Leaitch et al., 2009; Deboudt et al., 2010; Matsuki et al., $2010 \mathrm{~b}$ ). The presence of microorganisms on dust particles has been confirmed at various sites for Asian dust (Iwasaka et al., 2009), which is not surprising for surface soil particles. The impacts of these internal mixtures are unknown.

\subsection{Particle size distribution}

Newly available field data of airborne dust size distributions are compiled in Table 3 with respect to source areas and longrange transport regimes. Applied methods and the altitudes are listed as well. This information is also represented in a graphical form in Fig. 4. This compilation is mostly based on electron microscopy and optical-based measurements. In this sense, it complements the compilation which has been published by Reid et al. (2008) based on APS datasets available worldwide.

The analysis of the available data set is not straightforward due to the uncertainties in the experimental techniques and the difficulties in reconciling them (Sect. 2.1).

The prediction of the size distribution of mineral dust is an outstanding modelling issue. Various emission models based on different physical schemes (Alfaro et al., 1998; Lu and Shao, 1999; Alfaro and Gomes, 2001; Shao, 2001) describe the size distribution of mineral dust as determined by the saltation and sandblasting processes, which depending on the surface wind speed, and on soil characteristics such as dry size distribution, humidity and mineralogy (Marticorena and Bergametti, 1995; Fécan et al., 1998; Alfaro and Gomes, 2001; Prospero et al., 2002).

Recently, Sow et al. (2009) showed from the analysis of size-resolved vertical fluxes that only the fine mass particle fraction $(<2 \mu \mathrm{m}$ in diameter) is sensitive to wind speed and becomes relatively more important as wind speed increases. The presence of a submicron dust particle mode, up to now a debated issue in the literature (Gomes et al., 1990; Alfaro and Gomes, 2001; Reid et al., 2008), is also put into evidence. The Sow et al. (2009) observations are confirmed by most of the new data available for airborne dust after short-range transport (Chou et al., 2008; Osborne et al., 2008; McConnell et al., 2008; Weinzierl et al., 2009; Kandler et al., 2009), which all agree in showing that aluminosilicate dust particles in the diameter range between 0.1 and $0.5 \mu \mathrm{m}$ exist and might represent up to $40 \%$ of the total particle number. This fine mode is often mixed, internally or externally, with soot or sulphate particles (Chou et al., 2008; Kandler et al., 2007, 2009; Weinzierl et al., 2009).

The dynamics of coarse particles larger than $2 \mu \mathrm{m}$ in diameter shown by Sow et al. (2009) is different. In contrast with previous laboratory observations (Alfaro and Gomes, 2001), these authors suggest that the size distribution of the dust released by a given erosion event is fairly constant and insensitive to even relatively large variations of the friction velocity.

Then, the dynamics of the mass size distribution of advected dust after 1-2 days of transport has been investigated by Rajot et al. (2008) and Reid et al. (2008). Rajot et al. (2008) show that the coarse fraction is composed by two modes of geometric mean equal to $8.7 \mu \mathrm{m}$ and $4.7 \mu \mathrm{m}$, respectively. The first mode is dominant at the beginning of the event, but it loses importance with time after transport. 
Table 3. Dust size distributions covering the full size range; references are listed if parameterised size distributions are given. Abbreviations are CMD: count median diameter; GSD: geometric standard deviation; VMD: volume median diameter; a.s.l: above sea level; a.g.l.: above ground level; OPC: optical particle counter; APS: aerodynamic particle sizer; DMPS: differential mobility particle sizer.

\begin{tabular}{|c|c|c|c|c|c|c|c|c|c|c|}
\hline & \multirow[t]{2}{*}{ Dust source } & \multirow[t]{2}{*}{ Sampling location } & \multirow[t]{2}{*}{ Method } & \multirow[t]{2}{*}{ Altitude } & \multicolumn{3}{|c|}{ Dust coarse mode \#1 } & \multicolumn{3}{|c|}{ Dust coarse mode \#2 } \\
\hline & & & & & $\mathrm{CMD}(\mu \mathrm{m})$ & GSD & $\mathrm{VMD}(\mu \mathrm{m})$ & $\mathrm{CMD}(\mu \mathrm{m})$ & GSD & $\mathrm{VMD}(\mu \mathrm{m})$ \\
\hline \multicolumn{11}{|l|}{ Sahara near source } \\
\hline Osborne et al. (2008) & North of Niger & Niger & OPC & $<1500$ m a.s.1 & 2.0 & 1.3 & 2.4 & 3.9 & 1.4 & 5.1 \\
\hline \multirow[t]{2}{*}{ Chou et al. (2008) } & North of Niger & Niger & TEM/SEM & $<1500$ m a.s.1 & 1.2 & 1.6 & 2.3 & 4.4 & 1.4 & 6.2 \\
\hline & & & & & 0.7 & 1.4 & 1.0 & 1.5 & 2.0 & 6.3 \\
\hline \multirow[t]{7}{*}{ Weinzierl et al. (2009) } & NW Sahara & Morocco & DMPS-OPC & $562 \mathrm{~m}$ a.g.1. & 1.0 & 2.0 & 4.1 & 5.7 & 1.7 & 12.4 \\
\hline & & Morocco & DMPS-OPC & 1390 m a.g.l. & 1.1 & 2.1 & 5.4 & 5.9 & 1.6 & 10.8 \\
\hline & & Morocco & DMPS-OPC & 1875 m a.g.l. & 1.0 & 2.0 & 4.4 & 5.8 & 1.8 & 15.5 \\
\hline & & Morocco & DMPS-OPC & $2730 \mathrm{~m}$ a.g.l. & 0.9 & 2.1 & 4.6 & 5.2 & 1.7 & \\
\hline & & Morocco & DMPS-OPC & 3215 m a.g.l. & 1.1 & 2.0 & 5.1 & 6.3 & 1.8 & 16.7 \\
\hline & & Morocco & DMPS-OPC & $3900 \mathrm{~m}$ a.g.l. & 0.8 & 2.3 & 5.8 & 5.0 & 1.6 & 9.0 \\
\hline & & Morocco & DMPS-OPC & 4485 m a.g.l. & 1.0 & 2.0 & 3.7 & 6.2 & 1.9 & 19.5 \\
\hline \multirow[t]{2}{*}{ Kandler et al. (2009) } & NW Sahara & Morocco & DMPS-APS-impactor & Ground level & 1.7 & 3.7 & 3.5 & 153.9 & 1.4 & 210.4 \\
\hline & & Morocco & & & 0.7 & 1.8 & 3.5 & 31.1 & 2.5 & 374.1 \\
\hline Rajot et al. (2008) & Sahara & Niger & OPC & Ground level & 4.5 & & & 8.7 & & \\
\hline \multicolumn{11}{|l|}{ Sahara transport regime } \\
\hline McConnell et al. (2008) & Mauritania & Dakar coast & OPC & 1000 m a.s. 1. & 2.0 & 1.3 & 2.5 & & & \\
\hline McConnell et al. (2008) & Mauritania & Dakar coast & OPC & $1000 \mathrm{~m}$ a.s. 1. & 1.9 & 1.3 & 2.4 & & & \\
\hline Haywood et al. (2003a) & W Sahara & Cape Verde islands & $\mathrm{OPC}$ & & 2.1 & 1.3 & 2.6 & 3.6 & 1.5 & 5.9 \\
\hline Bates et al. (2002) & NW Sahara & Portuguese coast & DMPS-APS & sea level & 0.9 & 1.8 & 2.6 & & & \\
\hline de Reus et al. (2000) & NW Sahara & Tenerife & DMPS-OPC & FT & 0.6 & 2.5 & 6.8 & & & \\
\hline Wagner et al. (2009) & NW Sahara & Portugal & APS, DMPS-OPC & FT & 1.2 & 2.0 & 5.1 & 6.6 & 1.5 & 11.2 \\
\hline Maring et al. (2003) & NW Sahara & Canary Islands & APS & Izana (2360 ma.s.1.) & 0.3 & 2.4 & 3.4 & & & \\
\hline Maring et al. (2003) & NW Sahara & Puerto Rico & APS & sea level & 0.4 & 2.2 & 2.5 & & & \\
\hline \multicolumn{11}{|l|}{ Arabian Peninsula } \\
\hline Reid et al. (2008) & UAE sand fields & UAE coast & APS-cascade impactor & sea level & 0.7 & 2.0 & 2.9 & & & \\
\hline Reid et al. (2008) & Iraq & UAE coast & APS-cascade impactor & sea level & 1.2 & 1.9 & 4.1 & & & \\
\hline Reid et al. (2008) & Yemen/Oman & UAE coast & APS-cascade impactor & sea level & 0.5 & 2.2 & 3.5 & & & \\
\hline Bates et al. (2002) & Arabian Peninsula & Arabian Sea & DMPS-APS & sea level & 1.1 & 1.8 & 3.0 & & & \\
\hline \multicolumn{11}{|l|}{ Namibian desert } \\
\hline Haywood et al. (2003b) & Aged dust & Namibia & OPC & & 1.6 & 1.9 & 5.5 & & & \\
\hline Haywood et al. (2003b) & Dust + regional haze & Namibia & OPC & & 2.0 & 1.9 & 6.9 & & & \\
\hline \multicolumn{11}{|l|}{ Chinese deserts } \\
\hline Quinn et al. (2004) & Gobi/Taklimakan & Sea of Japan & DMPS-APS & sea level & 0.9 & 1.8 & 2.5 & & & \\
\hline Clarke et al. (2004) & Gobi/Taklimakan & Sea of Japan & DMA-OPC & $\mathrm{BL}$ & 1.8 & 1.9 & 5.5 & 8.7 & 1.5 & 14.2 \\
\hline Kobayashi et al. (2007) & Gobi/Taklimakan & Kofu, Japan & Coulter Mulitsizer & ground level & 0.8 & 2.1 & 4.3 & & & \\
\hline Kim et al. (2004) & Gobi/Taklimakan & Dunhuang, China & OPC & FT & 1.0 & 1.5 & 1.6 & & & \\
\hline Zhang et al. (2003c) & Gobi/Taklimakan & Zhenbeitai, China & cascade impactor & ground level & & $>2.0$ & $\cong 11$ & & & \\
\hline \multicolumn{11}{|l|}{ North America } \\
\hline Peters (2006) & Arizona desert & Phoenix, Arizona & APS & ground level & 1.6 & 1.9 & 5.4 & & & \\
\hline \multicolumn{11}{|l|}{ Global model data sets } \\
\hline Dentener et al. (2006) & AeroCom coarse mode & & & 1.3 & 2.0 & 5.5 & & & & \\
\hline Hess et al. (1998) & OPAC coarse mode & & & 3.8 & 2.2 & 22.0 & & & & \\
\hline
\end{tabular}

At contrary, the second mode gains in importance with time. This is consistent with the conclusions of Reid et al. (2008) suggesting that, for particles smaller than $10 \mu \mathrm{m}$ in diameter, the size characteristics of dust events from a single source are rather independent of wind speed and remain practically unchanged after 1-2 days of transport in the atmosphere. This would imply that, in the absence of wet deposition or cloud processing, the size distribution of mineral dust does not change during long-range transport. These results are in accordance with observations of the size distribution dynamics during long-range transport by Maring et al. (2003).

State-of-the-art emission models also consider that only the $\mathrm{PM}_{20}$ dust fraction is entrained vertically by sandblasting, while larger particles are only entrained horizontally in the saltation flux, being too heavy to become airborne by sandblasting (Alfaro et al., 1998). However, near-source groundbased data in dust storm conditions show a giant mode of particles larger than $20 \mu \mathrm{m}$ (Rajot et al., 2008; Kandler et al., 2009; Sow et al., 2009), and, in the proximity of source regions, airborne measurements in the boundary layer below $500 \mathrm{~m}$ show a large mode below $40 \mu \mathrm{m}$ diameter (Kandler et al., 2009; Weinzierl et al., 2009; Formenti et al., 2010). Coarse particles of tenths of micron in diameter are observed over Portugal after 3-4 days of transport (Wagner et al., 2009 ) and in the Caribbean after long-range transport (Formenti et al., 2001b; Reid et al., 2002). 


\subsection{Particle non-sphericity}

Mineral dust at the emission stage has a rather constant median aspect ratio between 1.6 and 1.7 for Saharan dust (Chou et al., 2008, Kandler et al., 2009) and between 1.4 and 1.5 for Asian dust (Okada et al., 2001). For comparison, ammonium sulphate particles usually have aspect ratios smaller than 1.3 (Kandler et al., 2009).

The size-dependence of the aspect ratio was found to be weak to negligible (Okada et al., 2001; Chou et al., 2008; Kandler et al., 2009). When a sufficiently large number of particles is analyzed, an aspect ratio distribution can be determined. For mineral dust, this distribution follows a lognormal shape, but is shifted, (Kandler et al., 2007, 2009), independent of particle size or mineralogical composition. While silicates in the Saharan desert usually have median aspect ratios of 1.6, halite (sodium chloride) and titanium oxide particles tend to have lower aspect ratios (1.4 to 1.5), whereas gypsum usually has higher ones. Carbonate particles are reported to have slightly lower values (Coz et al., 2009).

Only little work was carried out so far on the evolution of the particle shape during dust transport. The median aspect ratio does not change significantly during short-range transport (Kandler et al., 2007; Coz et al., 2009). Two studies report data for the long-range transport situation. At Puerto Rico, long-range transported Saharan dust showed a significantly higher aspect ratio of 1.9 while preserving the shifted log-normal shape of the density distribution (Reid et al., 2003b). On the other side, aerosol deposit analyses of Asian mineral dust in Japan resulted in significantly lower aspect ratios around 1.27 ( $\mathrm{Li}$ and Osada, 2007a). The combination of these two studies would lead to the conclusion that preferentially spherical particles are removed, which is consistent with the sedimentation theory saying that nonspherical particles have a lower sedimentation speed than spherical particles.

Various processes have a potential to change the average shape of the dust particles during transport: shapeselective removal (i.e. deposition), heterogeneous processing and cloud and ice nucleation. Shape-selective removal can either directly affect particles of the same composition, but different shape, or particles with different composition (and density), which is reflected as different shape. Thus, it could increase as well as decrease the average aspect ratio. In any case, it does not change the shape of single particles. In contrast, heterogeneous processing which can occur as in-cloud and out-of-cloud processing can change the shape of individual particles. The deposition of secondary material as well as the aggregation of different dust particles in a cloud droplet would lead to lower aspect ratios due to the surface tension of evaporating droplets. On the other hand, a slow crystallization of, for example, sulphates may lead to more needle-like particles and would increase the aspect ratio (Kandler et al., 2007). In addition, the heterogeneous processing depends on the particle composition. While silicates (e.g., clay minerals, quartz) usually are rather inert, especially carbonates react with acids in liquid phase, particularly nitric acid, resulting in formation of particles with lower aspect ratios (Laskin et al., 2005a, b).

Currently, only one publication is available presenting statistical information on the third dimension (Okada et al., 2001). The authors report the prevailing presence of platy particles for Asian dust with a median height-to-width ratio of 0.3 , and a limited dependence on particle size. Due to its relevance for modelling the optical properties (Mishchenko, 2009), the particle thickness should be given further attention in future work.

\section{Synthesis and recommendations}

This paper presents a synthesis of the recent data on physicochemical properties of mineral dust from African and Asian deserts which were presented at the Third International Workshop on Mineral Dust in September 2008 in Leipzig (Germany). Mineral dust is a multi-component, strongly size-dependent aerosol which requires the combination of various analytical techniques and sampling methods based on different physical principles. The synopsis of literature data is complicated by a strong dependence of the results on sampling and analytical methods. Most of the data stems from a number of regional studies which have been conducted in the last few years to target some of the major dust emission and export regions as it had been recommended by Sokolik et al. (2001).

The synthesis of the discussion and the recommendations that derive from that are summarized hereafter:

1. We encourage the definition of common procedures for data treatment and presentation. Log-normal fitting is a common practice for representing the particle size distribution (e.g., Haywood et al., 2003a; Weinzierl et al., 2009). However, there is no common practice in the way that log-normal fitting is performed. In particular, the number of modes is often increased to optimise the curve fit, regardless of their physical meaning. We recommend that, in addition to customised fits, authors should present fit parameters for physically-based modes in order to improve comparison with model results and help in evaluating the evolution with time of the size distribution at emission. Also, reporting systematically on the skewness of the fit could help in evaluating the extent of the modifications during transport (Reid et al., 2008). In order to serve both for comparison purposes and geophysical discussions, fitting parameters of the optically-based size distribution should be presented for the refractive index of the aerosol species under investigation. Furthermore the conversion of instrument response into particle size, i.e., the calibration function needs to be reported. 
2. Because of the dependence of particle number and mass on size, the use of certified collectors is recommended in order to reduce ambiguities when comparing results on composition, concentrations and size distribution. Sampling size limits of collectors should be indicated systematically.

3. Some significant progress has been made in characterising the dust properties close to source regions. Much of the investigation has focussed on the mineralogy of iron. Our synthesis on iron mineralogical speciation between oxide and structural iron concerns mainly African sources but very little the Asian dust. Recent field works confirm the laboratory conclusions of Journet et al. (2008) and emphasizes that the iron speciation in dust samples is critical to estimate its solubility (Paris et al., 2010). Thus, the ratio between oxide and structural iron could constitute a simple approach to better model the solubility of iron for dust transport models that focus on the role of iron in ocean biogeochemistry. For that, the determination of the oxide and structural iron content in dust samples should be systematic. The apportionment of iron oxide between goethite and hematite should be pursued as it might have implications for the optical properties (Lafon et al., 2006; McConnell et al., 2010). Currently, radiative transfer modelling studies do not take into account the apportionment of iron oxides between hematite and goethite (Sokolik and Toon, 1999; Miller et al., 2004; Balkanski et al., 2007; Heinold et al., 2008; Mallet et al., 2009).

4. The qualitative characterization of the composition of bulk dust - mainly via X-ray diffraction techniques is well-established, but its quantitative assessment is affected by the absence of calibration standards truly representative of the real mineralogy and the size distribution of in the ambient situation. That is particularly true for clays, which can account for a large fraction of the mineral dust mass in the suspended fraction, but whose mineralogy is extremely variable due to weathering, substitutions and impurities. To date, the only quantitative determination of the dust clay mineralogy based on calibration has been achieved by Caquineau et al. (1998). Nonetheless, minerals have different refractive indices and solubility properties, and their quantification is essential to estimate their impact.

5. In general terms, fingerprinting of source regions has been improved by investigating the elemental, mineralogical and isotopic ratios of dust composition. The inclusion of those field observations of the dust composition into regional and global climate models will require the development of a physics-based relationship to describe the chemical and mineralogical size-fractionation between soil and airborne dust (Rahn, 1976) so to allow the prediction of the dust composition based on maps of soil mineralogy.

6. Only few data sets on the shape of dust particles are available to date. Despite the physical diversity of the shape of individual particles, there are hints that the particle aspect ratio is a rather universal parameter which only weakly depends on particle composition, size, and source region. Data agree in showing that the particle aspect ratio distribution extends up to 5, whereas stateof-the art modelling of the optical properties of randomly oriented spheroids only allows to take into account values of the aspect ratio up to 3 (Dubovik et al., 2006). Veihelmann et al. (2004) suggests that extending the optical models from moderate to large aspect ratios should reduce the errors in the estimation of the optical properties. We recommend that data are gathered on a broader statistical basis in order to provide a robust parameterization of shape and the role of potential key parameters which could control its natural variability (like chemical composition and transport distance). In parallel, sensitivity modelling using the field data should be undertaken to evaluate if, although little, the variability of aspect ratio has an impact of the optical and radiative properties of mineral dust. Data on the third dimension of particles and the surface roughness are very rare but are needed for optical modelling (Nousiainen and Muinonen, 2007; Mishchenko, 2009). Currently, there are contradictions in the evolution of the aspect ratio during transport, though the data basis is quite small. Future analyses should focus systematically on the causes of shape change (due to particle removal or due to processing).

7. The evolution of mineral dust properties during transport deserves further and systematic investigation in order to highlight and parameterise the processes responsible for those changes. This recommendation was already part of the list of high-priority research needs which had been identified by Sokolik et al. (2001). Much of the field observations on the evolution of dust properties concern the description of changes of the single-particle composition due to particle mixing and heterogeneous reactions (Sect. 3.3.2). The uptake mechanisms of nitrate, chlorite (Zhang and Iwasaka, 2001; Sullivan et al., 2009; Tobo et al., 2010; Shi et al., 2008; Laskin et al., 2005) and sulfate (Manktelow et al., 2010; Krueger et al., 2003; Laskin et al., 2005a; Shi et al., 2008) on dust is a major finding in the last few years in dust chemistry. These studies should be pursued in order to determine the importance of compositional ageing in modifying the $\mathrm{CCN}$ and IN properties of mineral dust. These are not independent of particle size. Manktelow et al. (2010) suggest that processed dust is actually not a very important CCN compared to existing aerosol, regardless of how much it ages 
(mainly due to the low number concentration), whereas Levin et al. (1996, 2005) and Wurzler et al. (2000) indicate that dust act as efficient giant $\mathrm{CCN}$ after having undergone cloud processing in a marine/polluted environment. Surface ageing is one of the factors imputed for the large range (4 orders of magnitudes) of accommodation coefficients reported for various heterogeneous reactions (Atkinson, 2008).

8. We recommend that further attention is given to the deposition of organic acids on dust particles, as this process could increase the ability of the particles to absorb water vapour (Hatch et al., 2008). The development of techniques able to quantify the deposition of organic acids on individual dust particles, and, more in general, the internal mixing state at the surface and the bulk levels, should be pursued.

9. Because of its importance in determining the optical and radiative properties, the solubility and $\mathrm{CCN}$ capacity, the gaseous uptake efficiency, and the deposition of mineral dust, we propose that future research should focus on the outstanding issue of the prediction of the size distribution of mineral dust at emission and its dynamics evolution during transport. There are inherent experimental limitations in the measurements of the aerosol size distribution, and of that of the coarse fraction of dust in particular (Reid et al., 2003a). Nonetheless, the challenge of representing the full extent of the dust size distribution has to be pursued. Recent studies show the evidence of a submicron fraction of mineral dust (Chou et al., 2008; Osborne et al., 2008; McConnell et al., 2008; Weinzierl et al., 2009; Kandler et al., 2007, 2009). This fraction, surely persistent in the atmosphere in the absence of wet deposition, should be better constrained because of its radiative efficiency. This size fraction is currently represented by models but it is very variable (Huneeus et al., 2010). The presence of large airborne particles above $20 \mu \mathrm{m}$ in diameter was observed by various studies reported in Sect. 3.2. This has limited implications for radiation transfer, but it is important for modelling the mineral dust cycle and the impact of dust on ocean productivity. Modelling the uplifting and transport of such large particles will also represent a new serious challenge for transport models.

Future research should include dedicated near-source and medium-to-long range transport studies. We recommend that these studies focus on the representation of the physical and chemical processes which determine the dust physicochemical properties. In agreement with the recommendation by Redmond et al. (2010), a systematic linkage between field observations and laboratory studies should therefore be sought in order to advance our knowledge on those processes.

The prediction of the anthropogenic fraction of emitted mineral dust, i.e. the fraction of dust which is emitted by human-disturbed surfaces or as a result of anthropogenicinduced climatic change, remains an open issue (Forster et al., 2007). The anthropogenic fraction of dust only should be accounted when estimating the radiative forcing effect relevant to climate change (Forster et al., 2007). Possible differences between properties of mineral dust emitted from undisturbed to those of disturbed soils could be used to trace the relative magnitude of the anthropogenic fraction of the dust global emission. An indication could be the enhanced presence of organic material in soils which would be periodically laboured for agricultural purposes, or differences in the size distribution due to the modification of the friction velocity due to labouring. There is currently no experimental evidence of these effects.

\section{Appendix A}

\section{Acronyms}

\begin{tabular}{|c|c|}
\hline ACE-2 & The Aerosol Characterisation Experiment - 2 (Raes et al., 2000a) \\
\hline ADEC & Aeolian Dust Experiment on Climate Impact (Mikami et al., 2005) \\
\hline BoDEx & Bodélé Dust Experiment (Todd et al., 2008) \\
\hline SHADE & Saharan Dust Experiment (Tanré et al., 2003) \\
\hline PRIDE & Puerto Rico Dust Experiment (Reid and Maring, 2003) \\
\hline MINATROC & Mineral Dust and Tropospheric Chemistry (Balkanski et al., 2003) \\
\hline ACE-Asia & Aerosol Characterisation Experiment - Asia (Huebert et al., 2003) \\
\hline AMMA & $\begin{array}{l}\text { African Monsoon Multidisciplinary Analysis } \\
\text { (Redelsperger et al., 2006) }\end{array}$ \\
\hline DODO & Dust Outflow and Deposition to the Ocean (McConnell et al., 2008) \\
\hline DABEX & Dust and Biomass-burning Experiment (Osborne et al., 2008) \\
\hline GERBILS & $\begin{array}{l}\text { Geostationary Earth Radiation Budget Intercomparison of Long- } \\
\text { wave and Shortwave radiation (Marsham et al., 2008) }\end{array}$ \\
\hline SAMUM & Saharan Mineral Dust Experiment (Heintzenberg, 2009) \\
\hline CARIBIC & $\begin{array}{l}\text { Civil Aircraft for Remote Sensing and In-Situ-Measurements in the } \\
\text { Troposphere and Lower Stratosphere Based on the Instrumentation } \\
\text { Container Concept (Hermann et al., 2001) }\end{array}$ \\
\hline PELTI & $\begin{array}{l}\text { Passing Efficiency of an Airborne Low Turbulence Aerosol Inlet } \\
\text { (Huebert et al., 2004) }\end{array}$ \\
\hline
\end{tabular}

\section{Supplementary material related to this article is available online at: http://www.atmos-chem-phys.net/11/8231/2011/ acp-11-8231-2011-supplement.pdf.}

Acknowledgements. The authors acknowledge Irina Sokolik (GeorgiaTech, Atlanta) and Ina Tegen (Institute for Tropospheric Research, Leipzig) of the scientific organising committee and the many researchers present at the Third International Dust workshop in Leipzig. Gilles Bergametti (LISA, Crteil) is thanked for useful discussions.

Some of the research presented in this article is supported by the German Research Foundation (DFG contract FOR 539) in the framework of the research group SAMUM. Based on a French initiative, AMMA was built by an international scientific group and is currently funded by a large number of agencies, especially from France, the United Kingdom, the United States, and Africa. It has been the beneficiary of a major financial contribution from the European Community's Sixth Framework Research 
Programme. Detailed information on scientific coordination and funding is available on the AMMA International Web site at www.amma-international.org.

Edited by: K. Carslaw

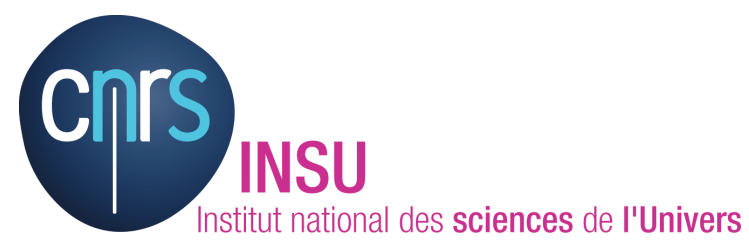

The publication of this article is financed by CNRS-INSU.

\section{References}

Alastuey, A., Querol, X., Castillo, S., Escudero, M., Avila, A., Cuevas, E., Torres, C., Romero, P.-M., Exposito, F., García, O., Pedro Diaz, J., Dingenen, R. V., and Putaud, J. P.: Characterisation of TSP and $\mathrm{PM}_{2.5}$ at Izaña and Sta. Cruz de Tenerife (Canary Islands, Spain) during a Saharan Dust Episode (July 2002), Atmos. Environ., 39, 4715-4728, 2005.

Alfaro, S. C. and Gomes, L.: Modeling mineral aerosol production by wind erosion: Emission intensities and aerosol size distributions in source areas, J. Geophys. Res., 106, 18075-18084, doi:10.1029/2000jd900339, 2001.

Alfaro, S. C., Gaudichet, A., Gomes, L., and Maillé, M.: Mineral aerosol production by wind erosion: aerosol particle sizes and binding energies, Geophys. Res. Lett., 25, 991-994, 1998.

Almeida-Prieto, S., Blanco-Méndez, J., and Otero-Espinar, F. J.: Microscopic image analysis techniques for the morphological characterization of pharmaceutical particles: Influence of the software, and the factor algorithms used in the shape factor estimation, Eur. J. Pharm. Biopharm., 67, 766-776, 2007.

Andreae, M. O. and Rosenfeld, D.: Aerosol-cloud-precipitation interactions. Part 1. The nature and sources of cloud-active aerosols, Earth-Sci. Rev., 89, 13-41, 2008.

Andreae, M. O., Charlson, R. J., Bruynseels, R., Storms, H., Grieken, R. V., and Maenhaut, W.: Internal mixture of sea salt, silicates, and excess sulfate in marine aerosols, Science, 232, 1620-1623, 1986.

Annegarn, H. J., Flanz, M., Kenntner, T., Kneen, M. A., Helas, G., and Piketh, S. J.: Airborne streaker sampling for PIXE analysis, Nuclear Instruments and Methods in Physics Research Section B: Beam Interactions with Materials and Atoms, 109-110, 548550, 1996.

Arimoto, R., Balsam, W., and Schloesslin, C.: Visible spectroscopy of aerosol particles collected on filters: iron-oxide minerals, Atmos. Environ., 36, 89-96, 2002.

Arimoto, R., Kim, Y. J., Kim, Y. P., Quinn, P. K., Bates, T. S., Anderson, T. L., Gong, S., Uno, I., Chin, M., Huebert, B. J., Clarke, A. D., Shinozuka, Y., Weber, R. J., Anderson, J. R., Guazzotti, S. A., Sullivan, R. C., Sodeman, D. A., Prather, K. A., and Sokolik, I. N.: Characterization of Asian Dust during ACE-Asia. Monitoring and modelling of Asian dust storms, Global Planet. Change, 52, 23-56, 2006.
Armstrong, J. T.: Quantitative elemental analysis of individual microparticles with electron beam instruments, in: Electron Probe Quantitation, edited by: Heinrich, K. F. J. \& Newbuery, D.E., Plenum Press, New York, 1991.

Avila, A., Quèralt-Mitjans, I., and Alarcon, M.: Mineralogical composition of African dust delivered by red rains over northeastern Spain, J. Geophys. Res., 102, 21977-21996, 1997.

Aymoz, G., Jaffrezo, J.-L., Jacob, V., Colomb, A., and George, Ch.: Evolution of organic and inorganic components of aerosol during a Saharan dust episode observed in the French Alps, Atmos. Chem. Phys., 4, 2499-2512, doi:10.5194/acp-4-2499-2004, 2004.

Balkanski, Y., Bauer, S. E., van Dingenen, R., Bonasoni, P., Schulz, M., Fischer, H., Gobbi, G. P., Hanke, M., Hauglustaine, D., Putaud, J. P., Stohl, A., and Raes, F.: The Mt Cimone, Italy, free tropospheric campaign: principal characteristics of the gaseous and aerosol composition from European pollution, Mediterranean influences and during African dust events, Atmos. Chem. Phys. Discuss., 3, 1753-1776, doi:10.5194/acpd-3-17532003, 2003.

Balkanski, Y., Schulz, M., Claquin, T., and Guibert, S.: Reevaluation of Mineral aerosol radiative forcings suggests a better agreement with satellite and AERONET data, Atmos. Chem. Phys., 7, 81-95, doi:10.5194/acp-7-81-2007, 2007.

Baron, P. A. and Willeke, K.: Aerosol measurement: Principles, techniques and applications, 2nd ed., John Wiley and Sons, New York, 2001.

Bates, T. S., Coffman, D. J., Covert, D. S., and Quinn, P. K.: Regional marine boundary layer aerosol size distributions in the Indian, Atlantic, and Pacific Oceans: A comparison of INDOEX measurements with ACE-1, ACE-2, and Aerosols99, J. Geophys. Res., 107, 8026, doi:10.1029/2001JD001174, 2002.

Bauer, S. E., Balkanski, Y., Schulz, M., Hauglustaine, D. A., and Dentener, F.: Global modeling of heterogeneous chemistry on mineral aerosol surfaces: Influence on tropospheric ozone chemistry and comparison to observations, J. Geophys. Res., 109, D02304, doi:10.1029/2003jd003868, 2004.

Bergametti, G., Gomes, L., Coudé-Gaussen, G., Rognon, P., and Coustumer, M.-N. L.: African dust observed over Canary Islands: Source-regions identification and transport pattern for some summer situations, J. Geophys. Res., 94, 14855-14864, 1989a.

Bergametti, G., Gomes, L., Remoudaki, E., Desbois, M., Martin, D., and Buat-Ménard, P.: Present transport and deposition patterns of African dusts to the north-western Mediterranean, in: Paleoclimatology and Paleometeorology: Modern and Past Patterns of Global Atmospheric Transport, edited by: Leinen, M. and Sarnthein, M., Kluwer Academic Publishers, 227-251, 1989 b.

Blanco, A., Dee Tomasi, F., Filippo, E., Manno, D., Perrone, M. R., Serra, A., Tafuro, A. M., and Tepore, A.: Characterization of African dust over southern Italy, Atmos. Chem. Phys., 3, 21472159, doi:10.5194/acp-3-2147-2003, 2003.

Brooks, N. and Legrand, M.: Dust variability over North Africa and rainfall in the Sahel, in: Linking climate change to land surface change, Advances in Global Change Research, Kluwer Academic Publishers, Dordrecht, 1-25, 2003.

Cakmur, R. V., Miller, R. L., Perlwitz, J., Geogdzhayev, I. V., Ginoux, P., Koch, D., Kohfeld, K. E., Tegen, I., and Zender, C. S.: Constraining the magnitude of the global dust cycle by minimiz- 
ing the difference between a model and observations, J. Geophys. Res., 111, D06207, doi:10.1029/2005jd005791, 2006.

Caquineau, S.: Les sources des aérosols sahariens transportés au dessus de l'Atlantique tropical Nord: localisation et caractéristiques minéralogiques, Thèse, Université Paris 12, 1997.

Caquineau, S., Gaudichet, A., Gomes, L., Magonthier, M. C., and Chatenet, B.: Saharan dust: Clay ratio as a relevant tracer to assess the origin of soil-derived aerosols, Geophys. Res. Lett., 25, 983-986, doi:10.1029/98g100569, 1998.

Caquineau, S., Gaudichet, A., Gomes, L., and Legrand, M.: Mineralogy of Saharan dust transported over northwestern tropical Atlantic Ocean in relation to source regions, J. Geophys. Res., 107, 4251, doi:10.1029/2000jd000247, 2002.

Castillo, S., Moreno, T., Querol, X., Alastuey, A., Cuevas, E., Herrmann, L., Mounkaila, M., and Gibbons, W.: Trace element variation in size-fractionated African desert dusts, J. Arid Environ., 72, 1034-1045, 2008.

Chen, J., Li, G., Yang, J., Rao, W., Lu, H., Balsam, W., Sun, Y., and $\mathrm{Ji}, \mathrm{J} .: \mathrm{Nd}$ and $\mathrm{Sr}$ isotopic characteristics of Chinese deserts: Implications for the provenances of Asian dust, Geochim. Cosmochim. Ac., 71, 3904-3-914, 2007.

Cheng, Y.-S., Yeh, H.-C., and Allen, M. D.: Dynamic Shape Factor of a Plate-Like Particle, Aerosol Sci. Technol., 8, 109-123, 1988.

Chester, R., Sharples, E. J., Sanders, G. S., and Saydam, A. C.: Saharan dust incursion over the Tyrrhenian Sea, Atmos. Environ., 18, 929-935, 1984.

Chester, R., Lin, F. J., and Murphy, K. J. T.: A three stage sequential leaching scheme for the characterisation of the sources and environmental mobility of trace metals in the marine aerosol, Environ. Technol. Lett., 10, 887-900, 1989.

Crowley, J. N., Ammann, M., Cox, R. A., Hynes, R. G., Jenkin, M. E., Mellouki, A., Rossi, M. J., Troe, J., and Wallington, T. J.: Evaluated kinetic and photochemical data for atmospheric chemistry: Volume V - heterogeneous reactions on solid substrates, Atmos. Chem. Phys., 10, 9059-9223, doi:10.5194/acp-10-90592010, 2010.

Chiapello, I., Bergametti, G., Gomes, L., Chatenet, B., Dulac, F., Pimenta, J., and Santos Suares, E.: An additional low layer transport of Sahelian and Saharan dust over the north-eastern tropical Atlantic., Geophys. Res. Lett., 22, 3191-3194, 1995.

Chiapello, I., Bergametti, G., Chatenet, B., Bousquet, P., Dulac, F., and Santos Suares, E.: Origins of African dust transported over the northeastern tropical Atlantic., J. Geophys. Res., 102, 1370113709, 1997.

Chiapello, I., Bergametti, G., Chatenet, B., Dulac, F., Jankowiak, I., Liousse, C., and Santos Suares, E.: Contribution of the different aerosol species to the aerosol mass load and optical depth over the northeastern tropical Atlantic., J. Geophys. Res., 104, 40254035, 1999.

Choi, Y.-S., Lindzen, R. S., Ho, C.-H., and Kim, J.: Space observations of cold-cloud phase change, P. Natl. Acad. Sci. USA, 107, 25, 2010.

Chou, C., Formenti, P., Maille, M., Ausset, P., Helas, G., Harrison, M., and Osborne, S.: Size distribution, shape, and composition of mineral dust aerosols collected during the African Monsoon Multidisciplinary Analysis Special Observation Period 0: Dust and Biomass-Burning Experiment field campaign in Niger, January 2006, J. Geophys. Res., 113, D00C10, doi:10.1029/2008jd009897, 2008.
Claquin, T., Schulz, M., Balkanski, Y., and Boucher, O.: Uncertainties in assessing radiative forcing by mineral dust., Tellus B, 50, 491-505, 1998.

Claquin, T., Schulz, M., and Balkanski, Y. J.: Modeling the mineralogy of atmospheric dust sources., J. Geophys. Res., 104, 22243 22256, 1999.

Clarke, A. D., Collins, W. G., Rasch, P. J., Kapustin, V. N., Moore, K., owell, S. H., and Fuelberg, H. E.: Dust and pollution transport on global scales: Aerosol measurements and model predictions, J. Geophys. Res., 106, 32555-532569, 2001.

Clarke, A. D., Shinozuka, Y., Kapustin, V. N., Howell, S., Huebert, B., Doherty, S., Anderson, T., Covert, D., Anderson, J., Hua, X., Moore Ii, K. G., McNaughton, C., Carmichael, G., and Weber, R.: Size distributions and mixtures of dust and black carbon aerosol in Asian outflow: Physiochemistry and optical properties, J. Geophys. Res., 109, D15S09, doi:10.1029/2003JD004378, 2004.

Collins, D. R., Johnsson, H. H., Seinfeld, J. H., Flagan, R. C., Gassó, S., Hegg, D. A., Russell, P. B., Schmid, B., Livingston, J. M., Öström, E., Noone, K. J., Russell, L. M., and Putaud, J. P.: In situ aerosol size distributions and clear column radiative closure during ACE-2, Tellus B, 52, 498-525, 2000.

Connolly, P. J., Mähler, O., Field, P. R., Saathoff, H., Burgess, R., Choularton, T., and Gallagher, M.: Studies of heterogeneous freezing by three different desert dust samples, Atmos. Chem. Phys., 9, 2805-2824, doi:10.5194/acp-9-2805-2009, 2009.

Cornille, P., Maenhaut, W., and Pacyna, J. M.: Sources and characteristics of the atmospheric aerosol near Damascus, Syria, Atmos. Environ., 24, 1083-1093, 1990.

Coudé-Gaussen, G.: Les poussières sahariennes, John Libbey Euro Text, 390 pp., 1991.

Coz, E., Gómez-Moreno, F. J., Pujadas, M., Casuccio, G. S., Lersch, T. L., and Artíñano, B.: Individual particle characteristics of North African dust under different long-range transport scenarios, Atmos. Environ., 43, 1850-1863, 2009.

Crumeyrolle, S., Gomes, L., Tulet, P., Matsuki, A., Schwarzenboeck, A., and Crahan, K.: Increase of the aerosol hygroscopicity by cloud processing in a mesoscale convective system: a case study from the AMMA campaign, Atmos. Chem. Phys., 8, 6907-6924, doi:10.5194/acp-8-6907-2008, 2008.

Cwiertny, D. M., Baltrusaitis, J., Hunter, G. J., Laskin, A., Scherer, M. M., and Grassian, V. H.: Characterization and acidmobilization study of iron-containing mineral dust source materials, J. Geophys. Res., 113, doi:10.1029/2007jd009332, 2008.

Deboudt, K., Flament, P., Choël, M., Gloter, A., Sobanska, S., and Colliex, C.: Mixing state of aerosols and direct observation of carbonaceous and marine coatings on African dust by individual particle analysis, J. Geophys. Res., 115, D24207, doi:10.1029/2010jd013921, 2010.

de Reus, M., Dentener, F., Thomas, A., Borrmann, S., Stroem, J., and Lelieveld, J.: Airborne observations of dust aerosol over the North Atlantic Ocean during ACE 2: Indications for heterogeneous ozone destruction, J. Geophys. Res., 105, 15263-15275, 2000.

de Reus, M., Fischer, H., Sander, R., Gros, V., Kormann, R., Salisbury, G., Van Dingenen, R., Williams, J., Zällner, M., and Lelieveld, J.: Observations and model calculations of trace gas scavenging in a dense Saharan dust plume during MINATROC, Atmos. Chem. Phys., 5, 1787-1803, doi:10.5194/acp-5-1787- 
2005, 2005.

DeMott, P. J., Sassen, K., Poellot, M. R., Baumgardner, D., Rogers, D. C., Brooks, S. D., Prenni, A. J., and Kreidenweis, S. M.: African dust aerosols as atmospheric ice nuclei, Geophys. Res. Lett., 30, 1732, doi:10.1029/2003g1017410, 2003.

DeMott, P. J., Prenni, A. J., Liu, X., Kreidenweis, S. M., Petters, M. D., Twohy, C. H., Richardson, M. S., Eidhammer, T., and Rodgers, D. C.: Predicting global atmospheric ice nuclei distributions and their impacts on climate, P. Natl. Acad. Sci. USA, 107, 11217-11222, 2010.

Dentener, F., Kinne, S., Bond, T., Boucher, O., Cofala, J., Generoso, S., Ginoux, P., Gong, S., Hoelzemann, J. J., Ito, A., Marelli, L., Penner, J. E., Putaud, J.-P., Textor, C., Schulz, M., van der Werf, G. R., and Wilson, J.: Emissions of primary aerosol and precursor gases in the years 2000 and 1750 prescribed data-sets for AeroCom, Atmos. Chem. Phys., 6, 4321-4344, doi:10.5194/acp6-4321-2006, 2006.

Desboeufs, K., Journet, E., Rajot, J. L., Chevaillier, S., Triquet, S., Formenti, P., and Zakou, A.: Chemistry of rain events in West Africa: evidence of dust and biogenic influence in convective systems, Atmos. Chem. Phys., 10, 9283-9293, doi:10.5194/acp10-9283-2010, 2010.

Dhaniyala, S., Flagan, R. C., McKinney, K. A., and Wennberg, P. O.: Novel Aerosol/Gas Inlet for Aircraft-Based Measurements, Aerosol Sci. Technol., 37, 828-840, 2003.

Dubovik, O., A. Sinyuk, T. Lapyonok, B. N. Holben, M. Mishchenko, P. Yang, T. F. Eck, Volten, H., Muñoz, O., Veihelmann, B., W. J. van der Zande, Leon, J.-F., Sorokin, M., and Slutsker, I.: Application of spheroid models to account for aerosol particle nonsphericity in remote sensing of desert dust, J. Geophys. Res., 111, D11208, doi:10.1029/2005JD006619, 2006.

Duce, R. A., Liss, P. S., Merrill, J. T., Atlas, E. L., Buat-Ménard, P., Hicks, B. B., Miller, J. M., Prospero, J. M., Arimoto, R., Church, T. M., Ellis, W., Galloway, J. N., Hansen, L., Jickels, T. D., Knap, A. H., Reinhardt, K. H., Schneider, B., Soudine, A., Tokos, J. J., Tsunogai, S., Wollast, R., and Zhou, M.: The atmospheric input of trace species to the world ocean, Global Biogeochem. Cy., 5, 193-259, 1991.

Dusek, U., Frank, G. P., Hildebrandt, L., Curtius, J., Schneider, J., Walter, S., Chand, D., Drewnick, F., Hings, S., Jung, D., Borrmann, S., and Andreae, M. O.: Size Matters More Than Chemistry for Cloud-Nucleating Ability of Aerosol Particles, Science, 312, 1375-1378, doi:10.1126/science.1125261, 2006.

Eastwood, M. L., Cremel, S., Gehrke, C., Girard, E., and Bertram, A. K.: Ice nucleation on mineral dust particles: Onset conditions, nucleation rates and contact angles, J. Geophys. Res.-Atmos., 113, D22203, doi:10.1029/2008JD010639, 2008.

Eltayeb, M. A. H., Xhoffer, C. F., Van Espen, P. J., Van Grieken, R., and Maenhaut, W.: Sources and composition of aerosol from Khartoum, Sudan, Atmos. Environ., 27, 67-76, 1993.

Esselborn, M., Wirth, M., Fix, A., Weinzierl, B., Rasp, K., Tesche, M., and Petzold, A.: Spatial distribution and optical properties of Saharan dust observed by airborne high spectral resolution lidar during SAMUM 2006, Tellus B, 61, 131-143, doi:10.1111/j.1600-0889.2008.00394.x, 2009.

Fairlie, T. D., Jacob, D. J., Dibb, J. E., Alexander, B., Avery, M. A., van Donkelaar, A., and Zhang, L.: Impact of mineral dust on nitrate, sulfate, and ozone in transpacific Asian pollution plumes, Atmos. Chem. Phys., 10, 3999-4012, doi:10.5194/acp-10-3999-
2010, 2010.

Falkovich, A. H., Ganor, E., Levin, Z., Formenti, P., and Rudich, Y.: Chemical and mineralogical analysis of individual mineral dust particles, J. Geophys. Res., 106, 18029-18036, doi:10.1029/2000jd900430, 2001.

Falkovich, A. H., Schkolnik, G., Ganor, E., and Rudich, Y.: Adsorption of organic compounds pertinent to urban environments onto mineral dust particles, J. Geophys. Res., 109, D02208, doi:10.1029/2003jd003919, 2004.

Fan, X.-B., Okada, K., Niimura, N., Kai, K., Arao, K., Shi, G.-Y., Qin, Y., and Mitsuta, Y.: Mineral particles collected in china and japan during the same Asian dust-storm event, Atmos. Environ., 30, 347-351, 1996.

Fan, S.-M., Moxim, W. J., and Levy II, H.: Aeolian input of bioavailable iron to the ocean, Geophys. Res. Lett., 33, L07602, doi:10.1029/2005g1024852, 2006.

Fécan, F., Marticorena, B., and Bergametti, G.: Parametrization of the increase of the aeolian erosion threshold wind friction velocity due to soil moisture for arid and semi-arid areas, Ann. Geophys., 17, 149-157, doi:10.1007/s00585-999-0149-7, 1998.

Formenti, P., Andreae, M. O., Andreae, T. W., Ichoku, C., Schebeske, G., Kettle, J., Maenhaut, W., Cafmeyer, J., Ptasinsky, J., Karnieli, A., and Lelieveld, J.: Physical and chemical characteristics of aerosols over the Negev Desert (Israel) during summer 1996, J. Geophys. Res., 106, 4871-4890, doi:10.1029/2000jd900556, 2001a.

Formenti, P., Andreae, M. O., Lange, L., Roberts, G., Cafmeyer, J., Rajta, I., Maenhaut, W., Holben, B. N., Artaxo, P., and Lelieveld, J.: Saharan dust in Brazil and Suriname during the Large-Scale Biosphere-Atmosphere Experiment in Amazonia (LBA) - Cooperative LBA Regional Experiment (CLAIRE) in March 1998, J. Geophys. Res., 106, 14919-14934, doi:10.1029/2000jd900827, 2001b.

Formenti, P., Elbert, W., Maenhaut, W., Haywood, J., and Andreae, M. O.: Chemical composition of mineral dust aerosol during the Saharan Dust Experiment (SHADE) airborne campaign in the Cape Verde region, September 2000, J. Geophys. Res., 108, 8576, doi:10.1029/2002jd002648, 2003.

Formenti, P., Rajot, J. L., Desboeufs, K., Caquineau, S., Chevaillier, S., Nava, S., Gaudichet, A., Journet, E., Triquet, S., Alfaro, S., Chiari, M., Haywood, J., Coe, H., and Highwood, E.: Regional variability of the composition of mineral dust from western Africa: Results from the AMMA SOP0/DABEX and DODO field campaigns, J. Geophys. Res., 113, D00C13, doi:10.1029/2008jd009903, 2008.

Formenti, P., Nava, S., Prati, P., Chevaillier, S., Klaver, A., Lafon, S., Mazzei, F., Calzolai, G., and Chiari, M.: Self-attenuation artifacts and correction factors of light element measurements by $\mathrm{X}$-ray analysis: Implication for mineral dust composition studies, J. Geophys. Res., 115, D01203, doi:10.1029/2009jd012701, 2010.

Forster, P., Ramaswamy, V., Artaxo, P., Berntsen, T., Betts, R., Fahey, D. W., Haywood, J., Lean, J., Lowe, D. C., Myhre, G., Nganga, J., Prinn, R., Raga, G., Schulz, M., and Van Dorland, R.: Changes in Atmospheric Constituents and in Radiative Forcing. Cambridge University Press, Cambridge, United Kingdom and New York, NY, USA, 2007.

Ganor, E., Foner, H., Brenner, S., Neeman, E., and Lavi, N.: Chemical composition of aerosols settling in Israel following dust 
storms, Atmos. Environ., 25, 2665-2670, 1991.

Gao, Y., Anderson, J. R., and Hua, X.: Dust characteristics over the North Pacific observed through shipboard measurements during the ACE-Asia experiment, Atmos. Environ., 41, 7907-7922, 2007.

Gibson, E. R., Hudson, P. K., and Grassian, V. H.: Aerosol chemistry and climate: Laboratory studies of the carbonate component of mineral dust and its reaction products, Geophys. Res. Lett., 33, L13811, doi:10.1029/2006g1026386, 2006.

Glaccum, R. A. and Prospero, J. M.: Saharan aerosols over the tropical north Atlantic - Mineralogy, Mar. Geol., 37, 295-321, 1980.

Gomes, L., Bergametti, G., Dulac, F., and Ezat, U.: Assessing the actual size distribution of atmospheric aerosols collected with a cascade impactor, J. Aerosol Sci., 21, 47-59, 1990.

Goudie, A. S.: Great warm deserts of the world, Oxford University Press, Oxford, 2003.

Goudie, A. S. and Middleton, N. J.: Saharan dust storms: nature and consequences, Earth-Sci. Rev. 56, 179-204, 2001.

Greenland, D. J., Oades, J. M., and Sherwin, T. W.: Electron microscope observations of iron oxides in some red soils, J. Soil Sci., 123-126, 1968.

Grousset, F. E. and Biscaye, P. E.: Tracing dust sources and transport patterns using $\mathrm{Sr}, \mathrm{Nd}$ and $\mathrm{Pb}$ isotopes, Chem. Geol., 222, 149-167, 2005.

Grousset, F. E., Rognon, P., Coudé-Gaussen, G., and Pédemay, P.: Origins of peri-Saharan dust deposits traced by their $\mathrm{Nd}$ and $\mathrm{Sr}$ isotopic composition., Palaeogeography, Palaeoclimatology, Palaeoecology, 93, 203-212, 1992.

Grousset, F. E., Parra, M., Bory, A., Martinez, P., Bertrand, P., Shimmield, G., and Ellam, R.: Saharan wind regimes traced by the Sr-Nd isotopic composition of the tropical Atlantic sediments: last glacial maximum vs. today, Quat. Sci. Rev., 17, 395409, 1998

Guieu, C., Bozec, Y., Blain, S., Ridame, C., Sarthou, G., and Leblond, N.: Impact of high Saharan dust inputs on dissolved iron concentrations in the Mediterranean Sea, Geophys. Res. Lett., 29, 1911, doi:10.1029/2001GL014454, 2002a.

Guieu, C., Loÿe-Pilot, M. D., Ridame, C., and Thomas, C.: Chemical characterization of the Saharan dust end-member: Some biogeochemical implications for the western Mediterranean Sea, J. Geophys. Res., 107, 4258, doi:10.1029/2001jd000582, 2002b.

Gustafsson, R. J., Orlov, A., Badger, C. L., Griffiths, P. T., Cox, R. A., and Lambert, R. M.: A comprehensive evaluation of water uptake on atmospherically relevant mineral surfaces: DRIFT spectroscopy, thermogravimetric analysis and aerosol growth measurements, Atmos. Chem. Phys., 5, 34153421, doi:10.5194/acp-5-3415-2005, 2005.

Gwaze, P., Annegarn, H. J., Huth, J., and Helas, G.: Comparison of particle sizes determined with impactor, AFM and SEM, Atmos. Res., 86, 93-104, 2007.

Hand, V. L., Capes, G., Vaughan, D. J., Formenti, P., Haywood, J. M., and Coe, H.: Evidence of internal mixing of African dust and biomass burning particles by individual particle analysis using electron beam techniques, J. Geophys. Res., 115, D13301, doi:10.1029/2009jd012938, 2010.

Hatch, C. D., Gierlus, K. M., Schuttlefield, J. D., and Grassian, V. H.: Water adsorption and cloud condensation nuclei activity of calcite and calcite coated with model humic and fulvic acids, Atmos. Environ., 42, 5672-5684, 2008.
Hatfield, R. G. and Maher, B. A.: Suspended sediment characterization and tracing using a magnetic fingerprinting technique: Bassenthwaite Lake, Cumbria, UK, The Holocene, 18(1), 105$115,2008$.

Haywood, J. M., Francis, P., Osborne, S., Glew, M., Loeb, N., Highwood, E., Tanré, D., Myhre, G., Formenti, P., and Hirst, E.: Radiative properties and direct radiative effect of Saharan dust measured by the C-130 aircraft during SHADE: 1 . Solar spectrum, J. Geophys. Res., 108, 8577, doi:10.1029/2002JD002687, 2003a.

Haywood, J. M., Osborne, S. R., Francis, P. N., Keil, A., Formenti, P., Andreae, M. O., and Kaye, P. H.: The mean physical and optical properties of regional haze dominated by biomass burning aerosol measured from the C-130 aircraft during SAFARI 2000, J. Geophys. Res., 108, 8473, doi:10.1029/2002JD002226, 2003 b.

Haywood, J. M., Johnson, B. T., Osborne, S. R., Baran, A. J., Brooks, M., Milton, S. F, Mulcahy, J., Walters, D., Allan, R. P., Klaver, A., Formenti, P., Brindley, H. E., Christopher, S., and Gupta, P.: Motivation, rationale and key results from the GERBILS Saharan dust measurement campaign, Q. J. R. Meteorol. Soc., 137, 1106-1116, doi:10.1002/qj.797, 2011.

Heinold, B., Tegen, I., Schepanski, K., and Hellmuth, O.: Dust radiative feedback on Saharan boundary layer dynamics and dust mobilization, Geophys. Res. Lett., 35, L20817, doi:10.1029/2008gl035319, 2008.

Heintzenberg, J.: The SAMUM-1 experiment over Southern Morocco: overview and introduction, Tellus B, 61, 2-11, doi:10.1111/j.1600-0889.2008.00403.x, 2009.

Helas, G. and Andreae, M. O.: Surface features on Sahara soil dust particles made visible by atomic force microscope (AFM) phase images, Atmos. Meas. Tech., 1, 1-8, doi:10.5194/amt-1-1-2008, 2008.

Hermann, M., Stratmann, F., Wilck, M., and Wiedensohler, A.: Sampling Characteristics of an Aircraft-Borne Aerosol Inlet System, J. Atmos. Ocean. Tech., 18, 7-19, doi:10.1175/1520-0426, 2001.

Hess, M., Koepke, P., and Schult, I.: Optical Properties of Aerosols and Clouds: The Software Package OPAC, B. Am. Meteorol. Soc., 79, 831-844, 1998.

Hinds, W. C.: Aerosol technology: properties, behavior, and measurement of airborne particles, John Wiley \& Sons, Chichester, 504 pp., 1999.

Hoffmann, P., Dedik, A. N., Ensling, J., Weinbruch, S., Weber, S., Sinner, T., Gütlich, P., and Ortner, H. M.: Speciation of iron in atmospheric aerosol samples, J. Aeros. Sci., 27, 325-337, 1996.

Huebert, B. J., Bates, T., Russell, P. B., Shi, G., Kim, Y. J., Kawamura, K., Carmichael, G., and Nakajima, T.: An overview of ACE-Asia: Strategies for quantifying the relationships between Asian aerosols and their climatic impacts, J. Geophys. Res., 108, 8633, doi:10.1029/2003jd003550, 2003.

Huebert, B. J., Howell, S. G., Covert, D., Bertram, T., Clarke, A., Anderson, J. R., Lafleur, B. G., Seebaugh, W. R., Wilson, J. C., Gesler, D., Blomquist, B., and Fox, a. J.: PELTI: Measuring the Passing Efficiency of an Airborne Low Turbulence Aerosol Inlet, Aerosol. Sci. Tech., 38, 803-826, 2004.

Huneeus, N., Schulz, M., Balkanski, Y., Griesfeller, J., Prospero, J., Kinne, S., Bauer, S., Boucher, O., Chin, M., Dentener, F., Diehl, T., Easter, R., Fillmore, D., Ghan, S., Ginoux, P., Grini, A., Horowitz, L., Koch, D., Krol, M. C., Landing, W., Liu, X., 
Mahowald, N., Miller, R., Morcrette, J.-J., Myhre, G., Penner, J., Perlwitz, J., Stier, P., Takemura, T., and Zender, C. S.: Global dust model intercomparison in AeroCom phase I, Atmos. Chem. Phys., 11, 7781-7816, doi:10.5194/acp-11-7781-2011, 2011.

Ichoku, C., Andreae, M. O., Andreae, T. W., Meixner, F. X., Schebeske, G., Formenti, P., Maenhaut, W., Cafmeyer, J., Ptasinski, J., Karnieli, A., and Orlovsky, L.: Interrelationships between aerosol characteristics and light scattering during late winter in an Eastern Mediterranean arid environment, J. Geophys. Res., 104, 24371-24393, doi:10.1029/1999jd900781, 1999.

Israelevich, P. L., Levin, Z., Joseph, J. H., and Ganor, E.: Desert aerosol transport in the Mediterranean region as inferred from the TOMS aerosol index, J. Geophys. Res., 107, 4572, doi:10.1029/2001jd002011, 2002.

Iwasaka, Y., Shi, G. Y., Yamada, M., Matsuki, A., Trochkine, D., Kim, Y. S., Zhang, D., Nagatani, T., Shibata, T., Nagatani, M., Nakata, H., Shen, Z., Li, G., and Chen, B.: Importance of dust particles in the free troposphere over the Taklamakan Desert: Electron microscopic experiments of particles collected with a balloonborne particle impactor at Dunhuang, China, J. Geophys. Res., 108, 8644, doi:10.1029/2002jd003270, 2003.

Iwasaka, Y., Shi, G. Y., Yamada, M., Kobayashi, F., Kakikawa, M., Maki, T., Naganuma, T., Chen, B., Tobo, Y., and Hong, C.: Mixture of Kosa (Asian dust) and bioaerosols detected in the atmosphere over the Kosa particles source regions with balloon-borne measurements: possibility of long-range transport, Air Quality, Atmosphere \& Health, 2, 29-38, doi:10.1007/s11869-009-00315, 2009.

Jeong, G. Y.: Bulk and single-particle mineralogy of Asian dust and a comparison with its source soils, J. Geophys. Res., 113, D02208, doi:10.1029/2007jd008606, 2008.

Jickells, T., and Spokes, L. J.: Atmospheric iron inputs to the oceans, in: The biogeochemistry of Iron in seawater, edited by: Turner, D. R. and Hunter, K. A., SCOR-IUPAC series, J Wiley, Baltimore, 85-121, 2001.

Jiménez-Vélez, B., Detrés, Y., Armstrong, R. A., and Gioda, A.: Characterization of African Dust $\left(\mathrm{PM}_{2.5}\right)$ across the Atlantic Ocean during AEROSE 2004, Atmos. Environ., 43, 2659-2664, 2009.

Journet, E., Desboeufs, K. V., Caquineau, S., and Colin, J.-L.: Mineralogy as a critical factor of dust iron solubility, Geophys. Res. Lett., 35, L07805, doi:10.1029/2007g1031589, 2008.

Kaaden, N., Massling, A., Schladitz, A., Müller, T., Kandler, K., Schütz, L., Weinzierl, B., Petzold, A., Tesche, M., Leinert, S., and Wiedensohler, A.: State of Mixing, Shape Factor, Number Size Distribution, and Hygroscopic Growth of the Saharan Anthropogenic and Mineral Dust Aerosol at Tinfou, Morocco, Tellus B, 61, 51-63, 2009.

Kahnert, M., Nousiainen, T., and Raisanen, P.: Mie simulations as an error source in mineral aerosol radiative forcing calculations, Q. J. Roy. Meteor. Soc., 133, 299-307, 2007.

Kalashnikova, O. V. and Sokolik, I. N.: Importance of shapes and compositions of wind-blown dust particles for remote sensing at solar wavelengths, Geophys. Res. Lett., 29, 10, 2002.

Kalderon-Asael, B., Erel, Y., Sandler, A., and Dayan, U.: Mineralogical and chemical characterization of suspended atmospheric particles over the east Mediterranean based on synoptic-scale circulation patterns, Atmos. Environ., 43, 3963-3970, 2009.

Kandler, K., Benker, N., Bundke, U., Cuevas, E., Ebert, M., Knip- pertz, P., Rodriguez, S., Schütz, L., and Weinbruch, S.: Chemical composition and complex refractive index of Saharan mineral dust at Izana, Tenerife (Spain) derived by electron microscopy, Atmos. Environ., 41, 8058-8074, 2007.

Kandler, K., Schütz, L., Deutscher, C., Ebert, M., Hofmann, H., Jäckel, S., Jaenicke, R., Knippertz, P., Lieke, K., Massling, A., Petzold, A., Schladitz, A., Weinzierl, B., Wiedensohler, A., Zorn, S., and Weinbruch, S.: Size distribution, mass concentration, chemical and mineralogical composition and derived optical parameters of the boundary layer aerosol at Tinfou, Morocco, during SAMUM 2006, Tellus B, 61, 32-50, doi:10.1111/j.16000889.2008.00385.x, 2009.

Karyampudi, V. M., Palm, S. P., Reagen, J. A., Fang, H., Grant, W. B., Hoff, R. M., Moulin, C., Pierce, H. F., Torres, O., Browell, E. V., and Melfi, S. H.: Validation of the Saharan dust plume conceptual model using lidar, Meteosat, and ECMWF data., B. Am. Meteorol. Soc., 80, 1045-1075, 1999.

Kellogg, C. A. and Griffin, D. W.: Aerobiology and the global transport of desert dust, Trends in Ecology and Evolution, 21, 638644, 2006.

Khiri, F., Ezaidi, A., and Kabbachi, K.: Dust deposits in SoussMassa basin, South-West of Morocco: granulometrical, mineralogical and geochemical characterization, Journal of African Earth Sciences, 39, 459-464, 2004.

Kim, K. W., He, Z., and Kim, Y. J.: Physicochemical characteristics and radiative properties of Asian dust particles observed at Kwangju, Korea, during the 2001 ACE-Asia intensive observation period, J. Geophys. Res., 109, D19S02, doi:10.1029/2003JD003693, 2004.

Kim, J., Jung, C. H., Choi, B.-C., Oh, S.-N., Brechtel, F. J., Yoon, S.-C., and Kim, S.-W.: Number size distribution of atmospheric aerosols during ACE-Asia dust and precipitation events, Atmos. Environ., 41, 4841-4855, 2007.

Klein, H., Nickovic, S., Haunold, W., Bundke, U., Nillius, B., Ebert, M., Weinbruch, S., Schuetz, L., Levin, Z., Barrie, L. A., and Bingemer, H.: Saharan dust and ice nuclei over Central Europe, Atmos. Chem. Phys., 10, 10211-10221, doi:10.5194/acp10-10211-2010, 2010.

Kobayashi, H., Arao, K., Murayama, T., Iokibe, K., Koga, R., and Shiobara, M.: High-resolution measurement of size distributions of Asian Dust using a Coulter multisizer, J. Ocean. Atmos. Technol., 24, 194-205, doi:10.1175/JTECH1965.1, 2007.

Koçak, M., Mihalopoulos, N., and Kubilay, N.: Chemical composition of the fine and coarse fraction of aerosols in the northeastern Mediterranean, Atmos. Environ., 41, 7351-7368, 2007.

Koda, S., Tanaka, K., Sakamoto, H., Matsuoka, T., and Nomura, H.: Sonochemical Efficiency during Single-Bubble Cavitation in Water, The J. Phys. Chem., 108, 11609-11612, doi:10.1021/jp0461908, 2004.

Koehler, K. A., Kreidenweis, S. M., DeMott, P. J., Petters, M. D., Prenni, A. J., and Carrico, C. M.: Hygroscopicity and cloud droplet activation of mineral dust aerosol, Geophys. Res. Lett., 36, L08805, doi:10.1029/2009g1037348, 2009.

Koren, I., Ganor, E., and Joseph, J. H.: On the relation between size and shape of desert dust aerosol, J. Geophys. Res., 106, 1804718054, 2001.

Kreidenweis, S. M., Koehler, K., DeMott, P. J., Prenni, A. J., Carrico, C., and Ervens, B.: Water activity and activation diameters from hygroscopicity data - Part I: Theory and appli- 
cation to inorganic salts, Atmos. Chem. Phys., 5, 1357-1370, doi:10.5194/acp-5-1357-2005, 2005.

Krueger, B. J., Grassian, V. H., Laskin, A., and Cowin, J. P.: The transformation of solid atmospheric particles into liquid droplets through heterogeneous chemistry: Laboratory insights into the processing of calcium containing mineral dust aerosol in the troposphere, Geophys. Res. Lett., 30, 1148, doi:10.1029/2002g1016563, 2003.

Kwon, H., Cho, S. H., Chun, Y., Lagarde, F., and Pershagen, G. P.: Effects of the Asian dust events on daily mortality in Seoul, Korea, Environ. Res., 90, 1-5, 2002.

Lacis, A. A. and Mishchenko, M. I.: Climate forcing, climate sensitivity, and climate response: A radiative modelling perspective on atmospheric aerosols, in: Aerosol Forcing of Climate, edited by: Charlson, R. J. and Heintzenberg, J., John Wiley \& Sons, Chichester, 11-42, 1995.

Lafon, S.: Les oxydes de fer dans l'aérosol désertique en relation avec ses propriétés optiques: caractérisation physico-chimique de poussières minérales générées en soufflerie, Ph.D. thesis, 325 pp., Univ. Paris 12, Val-de-Marne, Créteil, France, 2004.

Lafon, S., Rajot, J., Alfaro, S., and Gaudichet, A.: Quantification of iron oxides in desert aerosol., Atmos. Environ., 38, 1211-1218, 2004.

Lafon, S., Sokolik, I. N., Rajot, J. L., Caquineau, S., and Gaudichet, A.: Characterization of iron oxides in mineral dust aerosols: Implications for light absorption, J. Geophys. Res., 111, D21207, doi:10.1029/2005jd007016, 2006.

Laskin, A., Iedema, M. J., Ichkovich, A., Graber, E. R., Taraniukb, I., and Yinon, R.: Direct observation of completely processed calcium carbonate dust particles, Faraday Discuss., 130, 453468, 2005a.

Laskin, A., Wietsma, T. W., Krueger, B. J., and Grassian, V. H.: Heterogeneous chemistry of individual mineral dust particles with nitric acid: A combined CCSEM/EDX, ESEM, and ICP-MS study, J. Geophys. Res., 110, D10208, doi:10.1029/2004JD005206, 2005b.

Laurent, B., Marticorena, B., Bergametti, G., and Mei, F.: Modeling mineral dust emissions from Chinese and Mongolian deserts, Global Planet. Change, 52, 121-141, 2006.

Laurent, B., Marticorena, B., Bergametti, G., Léon, J. F., and Mahowald, N. M.: Modeling mineral dust emissions from the Sahara desert using new surface properties and soil database, J. Geophys. Res., 113, D14218, doi:10.1029/2007jd009484, 2008.

Lazaro, F. J., Gutiérrez, L., Barrón, V., and Gelado, M. D.: The speciation of iron in desert dust collected in Gran Canaria (Canary Islands): Combined chemical, magnetic and optical analysis, Atmos. Environ., 42, 8987-8996, 2008.

Leaitch, W. R., Macdonald, A. M., Anlauf, K. G., Liu, P. S. K., Toom-Sauntry, D., Li, S.-M., Liggio, J., Hayden, K., Wasey, M. A., Russell, L. M., Takahama, S., Liu, S., van Donkelaar, A., Duck, T., Martin, R. V., Zhang, Q., Sun, Y., McKendry, I., Shantz, N. C., and Cubison, M.: Evidence for Asian dust effects from aerosol plume measurements during INTEXB 2006 near Whistler, BC, Atmos. Chem. Phys., 9, 3523-3546, doi:10.5194/acp-9-3523-2009, 2009.

Lee, E.-H. and Sohn, B.-J.: Examining the impact of wind and surface vegetation on the Asian dust occurrence over three classified source regions, J. Geophys. Res., 114, D06205, doi:10.1029/2008jd010687, 2009.
Levin, Z., Ganor, E. and Gladstein, V.: The effects of desert particles coated with sulfate on rain formation in the eastern Mediterranean, J. Appl. Meteorol., 35, 1511-1523, 1996.

Levin, Z., A. Teller, E. Ganor, and Y. Yin: On the interactions of mineral dust, sea-salt particles, and clouds: A measurement and modeling study from the Mediterranean Israeli Dust Experiment campaign, J. Geophys. Res., 110, D20202, doi:10.1029/2005JD005810, 2005.

Li, J. and Osada, K.: Water-Insoluble Particles in Spring Snow at Mt. Tateyama, Japan: Characteristics of the Shape Factors and Size Distribution in Relation with their origin and Transportation, J. Meteorol. Soc. Jpn., 85, 137-149, 2007a.

Li, J. and Osada, K.: Preferential settling of elongated mineral dust particles in the atmosphere, Geophys. Res. Lett., 34, L17807, $2007 b$.

Li, G., Chen, J., Chen, Y., Yang, J., Ji, J., and Liu, L.: Dolomite as a tracer for the source regions of Asian dust, J. Geophys. Res., 112, D17201, doi:10.1029/2007jd008676, 2007.

Lu, H. and Shao, Y.: A new model for dust emission by saltation bombardment, J. Geophys. Res., 104, 16827-16842, doi:10.1029/1999jd900169, 1999.

Luo, C., Mahowald, N. M., Meskhidze, N., Chen, Y., Siefert, R. L., Baker, A. R., and Johansen, A. M.: Estimation of iron solubility from observations and a global aerosol model, J. Geophys. Res., 110, D23307, doi:10.1029/2005jd006059, 2005.

Ma, C.-J. and Choi, K.-C.: A Combination of Bulk and Single Particle Analyses for Asian Dust, Water Air Soil Poll., 183, 3-13, 2007.

Mallet, M., Tulet, P., Serça, D., Solmon, F., Dubovik, O., Pelon, J., Pont, V., and Thouron, O.: Impact of dust aerosols on the radiative budget, surface heat fluxes, heating rate profiles and convective activity over West Africa during March 2006, Atmos. Chem. Phys., 9, 7143-7160, doi:10.5194/acp-9-7143-2009, 2009.

Manktelow, P. T., Carslaw, K. S., Mann, G. W., and Spracklen, D. V.: The impact of dust on sulfate aerosol, $\mathrm{CN}$ and $\mathrm{CCN}$ during an East Asian dust storm, Atmos. Chem. Phys., 10, 365-382, doi:10.5194/acp-10-365-2010, 2010.

Maring, H., Savoie, D. L., Izaguirre, M. A., Custals, L., and Reid, J. S.: Mineral dust aerosol size distribution change during atmospheric transport, J. Geophys. Res., 108, 8592, doi:10.1029/2002jd002536, 2003.

Marsham, J. H., Parker, D. J., Grams, C. M., Johnson, B. T., Grey, W. M. F., and Ross, A. N.: Observations of mesoscale and boundary-layer scale circulations affecting dust transport and uplift over the Sahara, Atmos. Chem. Phys., 8, 6979-6993, doi:10.5194/acp-8-6979-2008, 2008.

Marticorena, B. and Bergametti, G.: Modeling the atmospheric dust cycle: 1. Design of a soil-derived dust emission scheme, J. Geophys. Res., 100, 16415-16430, doi:10.1029/95jd00690, 1995.

Mason, B. J.: The Physics of Clouds, Clarendon Press, Oxford, 660 pp., 1971.

Matsuki, A., Iwasaka, Y., Shi, G., Zhang, D., Trochkine, D., Yamada, M., Kim, Y.-S., Chen, B., Nagatani, T., Miyazawa, T., Nagatani, M., and Nakata, H.: Morphological and chemical modification of mineral dust: Observational insight into the heterogeneous uptake of acidic gases, Geophys. Res. Lett., 32, L22806, doi:10.1029/2005g1024176, 2005.

Matsuki, A., Quennehen, B., Schwarzenboeck, A., Crumeyrolle, S., Venzac, H., Laj, P., and Gomes, L.: Temporal and verti- 
cal variations of aerosol physical and chemical properties over West Africa: AMMA aircraft campaign in summer 2006, Atmos. Chem. Phys., 10, 8437-8451, doi:10.5194/acp-10-84372010, 2010a.

Matsuki, A., Schwarzenboeck, A., Venzac, H., Laj, P., Crumeyrolle, S., and Gomes, L.: Cloud processing of mineral dust: direct comparison of cloud residual and clear sky particles during AMMA aircraft campaign in summer 2006, Atmos. Chem. Phys., 10, 1057-1069, doi:10.5194/acp-10-1057-2010, $2010 \mathrm{~b}$.

McConnell, C. L., Highwood, E. J., Coe, H., Formenti, P., Anderson, B., Osborne, S., Nava, S., Desboeufs, K., Chen, G., and Harrison, M. A. J.: Seasonal variations of the physical and optical characteristics of Saharan dust: Results from the Dust Outflow and Deposition to the Ocean (DODO) experiment, J. Geophys. Res., 113, D14S05, doi:10.1029/2007jd009606, 2008.

McConnell, C. L., Formenti, P., Highwood, E. J., and Harrison, M. A. J.: Using aircraft measurements to determine the refractive index of Saharan dust during the DODO Experiments, Atmos. Chem. Phys., 10, 3081-3098, doi:10.5194/acp-10-3081-2010, 2010.

Mehra, O. P. and Jackson, M. L.: Iron oxide removal from soils and clays by a dithionite-citrate buffered with sodium bicarbonate, Clay Minerals, 7, 317-327, 1960.

Meskhidze, N., Chameides, W. L., and Nenes, A.: Dust and pollution: A recipe for enhanced ocean fertilization?, J. Geophys. Res., 110, D03301, doi:10.1029/2004jd005082, 2005.

Mikami, M., Aoki, T., Ishizuka, M., Yabum, S., Yamada, Y., Gao, W., and Zeng, F.: Observation of Number Concentration of Desert Aerosols in the South of the Taklimakan Desert, China, J. Meteorol. Soc. Jpn., 83A, 31-43, 2005.

Miller, R. L., Tegen, I., and Perlwitz, J.: Surface radiative forcing by soil dust aerosols and the hydrologic cycle, J. Geophys. Res., 109, D04203, doi:10.1029/2003jd004085, 2004.

Mishchenko, M. I.: Electromagnetic scattering by nonspherical particles: A tutorial review, J. Quant. Spectrosc. Ra., 110, 808-832, 2009.

Mishchenko, M. I., Travis, L. D., Kahn, R. A., and West, R. A.: Modeling phase functions for dustlike tropospheric aerosols using a shape mixture of randomly oriented polydisperse spheroids, J. Geophys. Res., 102, 16831-16848, 1997.

Möhler, O., DeMott, P. J., Vali, G., and Levin, Z.: Microbiology and atmospheric processes: the role of biological particles in cloud physics, Biogeosciences, 4, 1059-1071, doi:10.5194/bg-4-10592007, 2007.

Moore, D., and Reynolds, R. C.: X-ray diffraction and the identification and analysis of clay minerals, Oxford University Press, New York, 1997.

Mounkaila, M.: Spectral and mineralogical properties of potential dust sources on a transect from the Bodélé depression (Central Sahara) to the Lake Chad in the Sahel, Hohenheimer Bodenkundliche Hefte, 78, 1-311, 2006.

Müller, K., Lehmann, S., van Pinxteren, D., Gnauk, T., Niedermeier, N., Wiedensohler, A., and Herrmann, H.: Particle characterization at the Cape Verde atmospheric observatory during the 2007 RHaMBLe intensive, Atmos. Chem. Phys., 10, 2709-2721, doi:10.5194/acp-10-2709-2010, 2010.

Myhre, G. and Stordal, F.: Global sensitivity experiments of the radiative forcing due to mineral aerosols, J. Geophys. Res., 106, 18193-118204, 2001.
Ndour, M., D’Anna, B., George, C., Ka, O., Balkanski, Y., Kleffmann, J., Stemmler, K., and Ammann, M.: Impact of the photocatalytic properties of mineral dust on atmospheric composition, Geophys. Res. Lett., 35, L05812, doi:10.1029/2007GL032006, 2008.

Niemi, J. V., Tervahattu, H., Virkkula, A., Hillamo, R., Teinilä, K., Koponen, I. K., and Kulmala, M.: Continental impact on marine boundary layer coarse particles over the Atlantic Ocean between Europe and Antarctica, Atmos. Res., 75, 301-321, 2005.

Niimura, N., Okada, K., Fan, X.-B., Kai, K., Arao, K., Shi, G.Y., and Takahashi, S.: Formation of Asian dust-storm particles mixed internally with sea salt in the atmosphere, J. Meteorol. Soc. Jpn., 76, 275-288, 1998.

Nousiainen, T.: Optical modeling of mineral dust particles: A review, J. Quant. Spectrosc. Ra., 110, 1261-1279, 2009.

Nousiainen, T. and Muinonen, K.: Surface-roughness effects on single-scattering properties of wavelength-scale particles, J. Quant. Spectrosc. Ra., 106, 389-397, 2007.

O’Hara, S. L., Clarke, M. L., and Elatrash, M. S.: Field measurements of desert dust deposition in Libya, Atmos. Environ., 40, 3881-3897, 2006.

Ohta, A., Tsuno, H., Kagi, H., Kanai, Y., Nomura, M., Zhang, R., Terashima, N., and Imai, N.: Chemical compositions and XANES speciations of $\mathrm{Fe}, \mathrm{Mn}$ and $\mathrm{Zn}$ from aerosols collected in China and Japan during dust events, Geochem. J., 40, 363-376, 2006.

Okada, K. and Kai, K.: Features and elemental composition of mineral particles collected in Zhangye, China, J. Meteorol. Soc. Jpn., 73, 947-957, 1995.

Okada, K. and Kai, K.: Atmospheric mineral particles collected at Qira in the Taklamakan Desert, China, Atmos. Environ., 38, 6927-6935, 2004.

Okada, K., Naruse, H., Tanaka, T., Nemoto, O., Iwasaka, Y., Wu, P.M., Ono, A., Duce, R. A., Uematsu, M., Merrill, J. T., and Arao, K.: X-ray spectrometry of individual Asian dust-storm particles over the Japanese islands and the North Pacific Ocean, Atmos. Environ., 24, 1369-1378, 1990.

Okada, K., Heintzenberg, J., Kai, K., and Qin, Y.: Shape of atmospheric mineral particles collected in three Chinese arid-regions, Geophys. Res. Lett., 28, 3123-3126, 2001.

Osborne, S. R., Johnson, B. T., Haywood, J. M., Baran, A. J., Harrison, M. A. J., and McConnell, C. L.: Physical and optical properties of mineral dust aerosol during the Dust and Biomass-burning Experiment, J. Geophys. Res., 113, D00C03, doi:10.1029/2007jd009551, 2008.

Otto, S., de Reus, M., Trautmann, T., Thomas, A., Wendisch, M., and Borrmann, S.: Atmospheric radiative effects of an in situ measured Saharan dust plume and the role of large particles, Atmos. Chem. Phys., 7, 4887-4903, doi:10.5194/acp-7-4887-2007, 2007.

Paquet, H., Coudé-Gaussen, G., and Rognon, P.: Etude minéralogique de poussières sahariennes le long d'un itinéraire entre $19^{\circ}$ et $35^{\circ}$ de latitude nord, Révue de Géologie Dynamique et de Géographie Physique, 25, 257-265, 1984.

Paris, R., Desboeufs, K. V., Formenti, P., Nava, S., and Chou, C.: Chemical characterisation of iron in dust and biomass burning aerosols during AMMA-SOP0/DABEX: implication for iron solubility, Atmos. Chem. Phys., 10, 4273-4282, doi:10.5194/acp10-4273-2010, 2010. 
Parungo, F., Kopcewicz, B., Nagamoto, C., Schnell, R., Sheridan, P., Zhu, C., and Harris, J.: Aerosol Particles in the Kuwait Oil Fire Plumes: Their Morphology, Size Distribution, Chemical Composition, Transport, and Potential Effect on Climate, J. Geophys. Res., 97, 15867-15882, doi:10.1029/92jd01223, 1992.

Parungo, F., Nagamoto, C., Zhou, M.-Y., Hansen, A. D. A., and Harris, J.: Aeolian transport of aerosol black carbon from China to the ocean, Atmos. Environ., 28, 3251-3260, 1994.

Pekney, N. J. and Davidson, C. I.: Determination of trace elements in ambient aerosol samples, Anal. Chim. Ac., 540, 269-277, 2005.

Perez, L., Tobias, A., Querol, X., Künzli, N., Pey, J., Alastuev, A., Viana, M., Valero, N., González-Cabré M., and J., S. : Coarse particles from Saharan dust and daily mortality, Epidemiology, 19, 800-807, 2008.

Peters, T. M.: Use of the aerodynamic particle sizer to measure ambient $\mathrm{PM}_{10}-\mathrm{PM}_{2.5}$ : The coarse fraction of $\mathrm{PM}_{10}$, J. Air Waste Manage., 56, 411-416, 2006.

Petzold, A., Rasp, K., Weinzierl, B., Esselborn, M., Hamburger, T., Dörnbrack, A., Kandler, K., SchüTz, L., Knippertz, P., Fiebig, M., and Virkkula, A.: Saharan dust absorption and refractive index from aircraft-based observations during SAMUM 2006, Tellus B, 61, 118-130, doi:10.1111/j.1600-0889.2008.00383.x, 2009.

Podczeck, F., Rahman, S. R., and Newton, J. M.: Evaluation of a standardised procedure to assess the shape of pellets using image analysis, Int. J. Pharm., 192, 123-138, 1999.

Prenni, A. J., Petters, M. D., Kreidenweis, S. M., Heald, C. L., Martin, S. T., Artaxo, P., Garland, R. M., Wollny, A. G., and Pöschl, U.: Relative roles of biogenic emissions and Saharan dust as ice nuclei in the Amazon basin, Nat. Geosci., 2, 402-405, 2009.

Prospero, J.: Long-term measurements of the transport of African mineral dust to the southeastern United States: Implications for regional air quality, J. Geophys. Res., 104, 15917-15928, 1999.

Prospero, J. M., Ginoux, P., Torres, O., Nicholson, S. E., and Gill, T. E.: Environmental characterization of global sources of atmospheric soil dust identified with the Nimbus 7 Total Ozone Mapping Spectrometer (TOMS) absorbing aerosol product, Rev. Geophys., 40, 2-1-2-31, 2002.

Putaud, J. P., Van Dingenen, R., Dell'Acqua, A., Raes, F., Matta, E., Decesari, S., Facchini, M. C., and Fuzzi, S.: Size-segregated aerosol mass closure and chemical composition in Monte Cimone (I) during MINATROC, Atmos. Chem. Phys., 4, 889-902, doi:10.5194/acp-4-889-2004, 2004.

Pye, K.: Aeolian Dust and Dust Deposits, Academic Press, London, 334 pp., 1987.

Quinn, P. K., Coffman, D. J., Bates, T. S., Welton, E. J., Covert, D. S., Miller, T. L., Johnson, J. E., Maria, S., Russell, L., Arimoto, R., Carrico, C. M., Rood, M. J., and Anderson, J.: Aerosol optical properties measured on board the Ronald H. Brown during ACE-Asia as a function of aerosol chemical composition and source region, J. Geophys. Res., 109, doi:10.1029/2003JD004010, 2004.

Raes, F., Dingenen, R. V., Vignati, E., Wilson, J., Putaud, J.-P., Seinfeld, J. H., and Adams, P.: Formation and cycling of aerosols in the global troposphere, Atmos. Environ., 34, 4215-4240, 2000a.

Raes, F., Bates, T., McGovern, F., and Van Liedekerke, M.: The 2nd Aerosol Characterization Experiment (ACE-2): general overview and main results, Tellus B, 52, 111-125, doi:10.1034/j.1600-0889.2000.00124.x, 2000b.

Rahn, K. A.: Silicon and aluminum in atmospheric aerosols: crustair fractionation?, Atmos. Environ., 10, 597-601, 1976.

Rajot, J. L., Formenti, P., Alfaro, S., Desboeufs, K., Chevaillier, S., Chatenet, B., Gaudichet, A., Journet, E., Marticorena, B., Triquet, S., Maman, A., Mouget, N., and Zakou, A.: AMMA dust experiment: An overview of measurements performed during the dry season special observation period (SOP0) at the Banizoumbou (Niger) supersite, J. Geophys. Res., 113, D00C14, doi:10.1029/2008jd009906, 2008.

Redelsperger, J.-L., Thorncroft, C. D., Diedhiou, A., Lebel, T., Parker, D. J., and Polcher, J.: African Monsoon Multidisciplinary Analysis: An International Research Project and Field Campaign, B. Am. Meteorol. Soc., 87, 1739-1746, doi:10.1175/BAMS-87-12-1739, 2006.

Redmond, H. E., Dial, K. D., and Thompson, J. E.: Light scattering and absorption by wind blown dust: Theory, measurement, and recent data, Aeolian Res., 2, 5-26, 2010.

Reid, J. S, and Maring, H. B.: Foreword to special section on the Puerto Rico Dust Experiment (PRIDE), J. Geophys. Res., 108, 8585, doi:10.1029/2003jd003510, 2003.

Reid, J. S., Westphal, D. L., Livingston, J. M., Savoie, D. L., Maring, H. B., Jonsson, H. H., Eleuterio, D. P., Kinney, J. E., and Reid, E. A.: Dust vertical distribution in the Caribbean during the Puerto Rico Dust Experiment, Geophys. Res. Lett., 29, 1151, doi:10.1029/2001g1014092, 2002.

Reid, J. S., Jonsson, H. H., Maring, H. B., Smirnov, A., Savoie, D. L., Cliff, S. S., Reid, E. A., Livingston, J. M., Meier, M. M., Dubovik, O., and Tsay, S. C.: Comparison of size and morphological measurements of coarse mode dust particles from Africa, J. Geophys. Res., 108, doi:10.1029/2002JD002485, 2003 a.

Reid, E. A., Reid, J. S., Meier, M. M., Dunlap, M. R., Cliff, S. S., Broumas, A., Perry, K., and Maring, H.: Characterization of African dust transported to Puerto Rico by individual particle and size segregated bulk analysis, J. Geophys. Res., 108, 8591, doi:10.1029/2002jd002935, 2003b.

Reid, J. S., Reid, E. A., Walker, A., Piketh, S., Cliff, S., Mandoos, A. A., Tsay, S.-C., and Eck, T. F.: Dynamics of southwest Asian dust particle size characteristics with implications for global dust research, J. Geophys. Res., 113, doi:10.1029/2007JD009752, 2008.

Ro, C., Huwang, H., Kim, H., Chun, Y., and Grieken, R. V.: Singleparticle characterization of four "Asian dust" samples collected in Korea, using low-Z particle electron probe X-ray microanalysis, Environ. Sci. Technol., 39, 1409-1419, 2005.

Schepanski, K., Tegen, I., Todd, M. C., Heinold, B., Bönisch, G., Laurent, B., and Macke, A.: Meteorological processes forcing Saharan dust emission inferred from MSG-SEVIRI observations of subdaily dust source activation and numerical models, J. Geophys. Res., 114, D10201, doi:10.1029/2008jd010325, 2009.

Schnell, R. C. and Vali, G.: Atmospheric ice nuclei from decomposing vegetation, Nature, 236, 163-165, 1972.

Schroth, A. W., Crusius, J., Sholkovitz, E. R., and Bostick, B. C.: Iron solubility driven by speciation in dust sources to the ocean, Nat. Geosci., 2, 337-340, 2009.

Schütz, L. and Sebert, M.: Mineral aerosols and source identification., J. Aerosol Sci., 18, 1-10, 1987.

Shao, Y.: A model for mineral dust emission, J. Geophys. Res., 106, 20239-20254, doi:10.1029/2001jd900171, 2001. 
Shao, Y. and Dong, C. H.: A review on East Asian dust storm climate, modelling and monitoring, Global Planet.Change, 52, 122, 2006.

Shen, Z. X., Li, X., Cao, J., Caquineau, S., Wang, Y., and Zhang, $X .:$ Characteristics of clay minerals in Asian dust and their environmental significance, China Particuology, 3, 260-264, 2005.

Shen, Z. X., Cao, J., Li, X., Okuda, T., Wang, Y., and Zhang, X.: Mass concentration and mineralogical characteristics of aerosol particles collected at Dunhuang during ACE-Asia, Adv. Atmos. Sci., 23, 291-298, 2006.

Shi, Z., Zhang, D., Hayashi, M., Ogata, H., Ji, H., and Fujiie, W.: Influences of sulfate and nitrate on the hygroscopic behaviour of coarse dust particles, Atmos. Environ., 42, 822-827, 2008.

Shinn, E. A., Smith, G. W., Prospero, J. M., Betzer, P., Hayes, M. L., Garrison, V., and Barber, R. T.: African dust and the demise of Caribbean Coral Reefs, Geophys. Res. Lett., 27, 3029-3032, doi:10.1029/2000g1011599, 2000.

Singer, A., Dultz, S., and Argaman, E.: Properties of the nonsoluble fractions of suspended dust over the Dead Sea, Atmos. Environ., 38, 1745-1753, 2004.

Sobanska, S., Coeur, C., Maenhaut, W., and Adams, F.: SEM-EDX Characterisation of Tropospheric Aerosols in the Negev Desert (Israel), J. Atmos. Chem., 44, 299-322, doi:10.1023/a:1022969302107, 2003.

Sokolik, I. and Toon, O.: Incorporation of mineralogical composition into models of the radiative properties of mineral aerosol from UV to IR wavelengths, J. Geophys. Res., 104, 9423-9444, 1999.

Sokolik, I. N., Winker, D. M., Bergametti, G., Gillette, D. A., Carmichael, G., Kaufman, Y. J., Gomes, L., Schuetz, L., and Penner, J. E.: Introduction to special section: Outstanding problems in quantifying the radiative impacts of mineral dust, J. Geophys. Res., 106, 18015-18027, doi:10.1029/2000jd900498, 2001.

Sow, M., Alfaro, S. C., Rajot, J. L., and Marticorena, B.: Size resolved dust emission fluxes measured in Niger during 3 dust storms of the AMMA experiment, Atmos. Chem. Phys., 9, 38813891, doi:10.5194/acp-9-3881-2009, 2009.

Stuut, J.-B., Zabel, M., Ratmeyer, V., Helmke, P., Schefuß, E., Lavik, G., and Schneider, R.: Provenance of present-day eolian dust collected off NW Africa, J. Geophys. Res., 110, D04202, doi:10.1029/2004JD005161, 2005.

Sullivan, R. C. and Prather, K. A.: Investigations of the diurnal cycle and mixing state of oxalic acid in individual particles in Asian aerosol outflow, Environ. Sci. Technol., 41, 8062-8069, 2007.

Sullivan, R. C., Guazzotti, S. A., Sodeman, D. A., and Prather, K. A.: Direct observations of the atmospheric processing of Asian mineral dust, Atmos. Chem. Phys., 7, 1213-1236, doi:10.5194/acp-7-1213-2007, 2007a.

Sullivan, R. C., Guazzotti, S. A., Sodeman, D. A., Tang, Y., Carmichael, G. R., and Prather, K. A.: Mineral dust is a sink for chlorine in the marine boundary layer, Atmos. Environ., 41, 7166-7179, 2007b.

Sullivan, R. C., Moore, M. J. K., Petters, M. D., Kreidenweis, S. M., Roberts, G. C., and Prather, K. A.: Effect of chemical mixing state on the hygroscopicity and cloud nucleation properties of calcium mineral dust particles, Atmos. Chem. Phys., 9, 33033316, doi:10.5194/acp-9-3303-2009, 2009.

Sun, J.: Source regions and formation of the Loess sediments on the High Mountain Regions of Northwestern China, Quaternary Res., 58, 341-351, doi:10.1006/qres.2002.2381, 2002 a.

Sun, J.: Provenance of loess material and formation of loess deposits on the Chinese Loess Plateau, Earth Planet. Sci. Lett., 203, 845-859, 2002b.

Sun, J., Zhang, M., and Liu, T.: Spatial and temporal characteristics of dust storms in China and its surrounding regions: Relations to source area and climate, J. Geophys. Res., 106, 10325-10333, doi:10.1029/2000jd900665, 2001.

Sun, Y., Tada, R., Chen, J., Chen, H., Toyoda, S., Tani, A., Isozaki, Y., Nagashima, K., Hasegawa, H., and Ji, J.: Distinguishing the sources of Asian dust based on electron spin resonance signal intensity and crystallinity of quartz, Atmos. Environ., 41, 85378548, 2007.

Svensson, A., Biscaye, P. E., and Grousset, F. E.: Characterization of late glacial continental dust in the Greenland Ice Core Project ice core, J. Geophys. Res., 105, 4637-4656, doi:10.1029/1999jd901093, 2000.

Tanré, D., Haywood, J., Pelon, J., Léon, J. F., Chatenet, B., Formenti, P., Francis, P., Goloub, P., Highwood, E. J., and Myhre, G.: Measurement and modeling of the Saharan dust radiative impact: Overview of the Saharan Dust Experiment (SHADE), J. Geophys. Res., 108, 8574, doi:10.1029/2002jd003273, 2003.

Textor, C., Schulz, M., Guibert, S., Kinne, S., Balkanski, Y., Bauer, S., Berntsen, T., Berglen, T., Boucher, O., Chin, M., Dentener, F., Diehl, T., Feichter, J., Fillmore, D., Ginoux, P., Gong, S., Grini, A., Hendricks, J., Horowitz, L., Huang, P., Isaksen, I. S. A., Iversen, T., Kloster, S., Koch, D., Kirkevg, A., Kristjansson, J. E., Krol, M., Lauer, A., Lamarque, J. F., Liu, X., Montanaro, V., Myhre, G., Penner, J. E., Pitari, G., Reddy, M. S., Seland, Ã., Stier, P., Takemura, T., and Tie, X.: The effect of harmonized emissions on aerosol properties in global models: an AeroCom experiment, Atmos. Chem. Phys., 7, 4489-4501, doi:10.5194/acp-7-4489-2007, 2007.

Tobo, Y., Zhang, D., Nakata, N., Yamada, M., Ogata, H., Hara, K., and Iwasaka, Y.: Hygroscopic mineral dust particles as influenced by chlorine chemistry in the marine atmosphere, Geophys Res. Lett., 36, L05817, doi:10.1029/2008g1036883, 2009.

Tobo, Y., Zhang, D., Matsuki, A., and Iwasaka, Y.: Asian dust particles converted into aqueous droplets under remote marine atmospheric conditions, P. Natl. Acad. Sci., 107, 17905-17910, doi:10.1073/pnas.1008235107, 2010.

Todd, M. C., Bou Karam, D., Cavazos, C., Bouet, C., Heinold, B., Baldasano, J. M., Cautenet, G., Koren, I., Perez, C., Solmon, F., Tegen, I., Tulet, P., Washington, R., and Zakey, A.: Quantifying uncertainty in estimates of mineral dust flux: An intercomparison of model performance over the Bodélé Depression, northern Chad, J. Geophys. Res., 113, D24107, doi:10.1029/2008jd010476, 2008.

Trochkine, D., Iwasaka, Y., Matsuki, A., Yamada, M., Kim, Y. S., Nagatani, T., Zhang, D., Shi, G. Y., and Shen, Z.: Mineral aerosol particles collected in Dunhuang, China, and their comparison with chemically modified particles collected over Japan, J. Geophys. Res., 108, 8642, doi:10.1029/2002jd003268, 2003.

van den Heever, S. C., Carrié, G. G., Cotton, W. R., DeMott, P. J., and Prenni, A. J.: Impacts of Nucleating Aerosol on Florida Storms. Part I: Mesoscale Simulations, J. Atmos. Sci., 63, 17521775, doi:10.1175/JAS3713.1, 2006.

Veihelmann, B., Volten, H., and van der Zande, W. J.: 
Light reflected by an atmosphere containing irregular mineral dust aerosol, Geophys. Res. Lett., 31, L04113, doi:10.1029/2003g1018229, 2004.

von der Weiden, S. L., Drewnick, F., and Borrmann, S.: Particle Loss Calculator: a new software tool for the assessment of the performance of aerosol inlet systems, Atmos. Meas. Tech., 2, 479-494, doi:10.5194/amt-2-479-2009, 2009.

Wagner, F., Bortoli, D., Pereira, S., Costa, M., Silva, A. M., Weinzierl, B., Esselborn, M., Petzold, A., Rasp, K., Heinold, B., and Tegen, I.: Properties of dust aerosol particles transported to Portugal from the Sahara desert, Tellus B, 61, 297-306, 2009.

Wandinger, U., Tesche, M., Seifert, P., Ansmann, A., Müller, D., and Althausen, D.: Size matters: Influence of multiple scattering on CALIPSO light-extinction profiling in desert dust, Geophys. Res. Lett., 37, L10801, doi:10.1029/2010g1042815, 2010.

Wang, J., Flagan, R. C., Seinfeld, J. H., Jonsson, H. H., Collins, D. R., Russell, P. B., Schmid, B., Redemann, J., Livingston, J. M., Gao, S., Hegg, D. A., Welton, E. J., and Bates, D.: Clearcolumn radiative closure during ACE-Asia: Comparison of multiwavelength extinction derived from particle size and composition with results from Sun photometry, J. Geophys. Res., 107, 4688, doi:10.1029/2002JD002465, 2002.

Wang, X., Huang, J., Ji, M., and Higuchi, K.: Variability of East Asia dust events and their long-term trend, Atmos. Environ., 42, 3156-3165, 2008.

Weinbruch, S., Wentzel, M., Kluckner, M., Hofmann, P., and Ortner, H. M.: Characterization of individual atmospheric particles by element mapping in electron probe microanalysis, Microchim. Acta, 125, 137-141, 1997.

Weinzierl, B., Petzold, A., Esselborn, M., Wirth, M., Rasp, K., Kandler, K., Schütz, L., Koepke, P., and Fiebig, M.: Airborne measurements of dust layer properties, particle size distribution and mixing state of Saharan dust during SAMUM 2006, Tellus B, 61, 96-117, doi:10.1111/j.1600-0889.2008.00392.x, 2009.

Wendisch, M., Coe, H., Baumgardner, D., Brenguier, J.-L., Dreiling, V., Fiebig, M., Formenti, P., Hermann, M., Krämer, M., Levin, Z., Maser, R., Mathieu, E., Nacass, P., Noone, K., Osborne, S., Schneider, J., Schütz, L., Schwarzenböck, A., Stratmann, F., and Wilson, J. C.: Aircraft Particle Inlets: State-ofthe-Art and Future Needs, B. Amer. Metoerol., Soc., 85, 89-91, doi:10.1175/BAMS-85-1-89, 2004.

Wurzler, S., Reisin, T. G. and Levin, Z.: Modification of mineral dust particles by cloud processing and subsequent effects on drop size distributions, J. Geophys. Res., 105, 4501, doi:10.1029/1999JD900980, 2000.

Xuan, J., Sokolik, I. N., Hao, J., Guo, F., Mao, H., and Yang, G.: Identification and characterization of sources of atmospheric mineral dust in East Asia, Atmos. Environ., 38, 6239-6252, 2004.

Yang, J., Li, G., Rao, W., and Ji, J.: Isotopic evidences for provenance of East Asian Dust, Atmos. Environ., 43, 4481-4490, 2009.
Zender, C. S., Miller, R., and Tegen, I.: Quantifying mineral dust mass budgets: Terminology, constraints, and current estimates, Eos Trans AGU, 85, 48, 2004.

Zhang, G.: Atmospheric particulate matter studied by Mössbauer spectroscopy and XAFS, Hyperfine Interactions, 151-152, 299306, doi:10.1023/b:hype.0000020421.68173.55, 2003.

Zhang, D.: Effect of sea salt on dust settling to the ocean, Tellus, 641-646, 2008.

Zhang, D. and Iwasaka, Y.: Chlorine deposition on dust particles in marine atmosphere, Geophys. Res. Lett., 28, 3613-3616, 2001.

Zhang, D., Iwasaka, Y., Shi, G., Zang, J., Matsuki, A., and Trochkine, D.: Mixture state and size of Asian dust particles collected at southwestern Japan in spring 2000, J. Geophys. Res., 108, 4760, doi:10.1029/2003jd003869, 2003a.

Zhang, D., Zang, J., Shi, G., Iwasaka, Y., Matsuki, A., and Trochkine, D.: Mixture state of individual Asian dust particles at a coastal site of Qingdao, China, Atmos. Environ., 37, 38953901, 2003b.

Zhang, X. Y., Gong, S. L., Arimoto, R., Shen, Z. X., Mei, F. M., Wang, D., and Cheng, Y.: Characterization and temporal variation of Asian dust aerosol from a site in the northern Chinese deserts, J. Atmos. Chem., 44, 241-257, 2003c.

Zhang, X. Y., Gong, S. L., Shen, Z. X., Mei, F. M., Xi, X. X., Liu, L. C., Zhou, Z. J., Wang, D., Wang, Y. Q., and Cheng, Y.: Characterization of soil dust aerosol in China and its transport and distribution during 2001 ACE-Asia: 1. Network observations, J. Geophys. Res., 108, 4261, doi:10.1029/2002jd002632, 2003 d.

Zhang, D., Iwasaka, Y., and Shi, G.: Sea salt shifts the range sizes of Asian dust, EOS Trans. AGU, 86, 523, 2005.

Zhang, D., Iwasaka, Y., Matsuki, A., Ueno, K., and Matsuzaki, T.: Coarse and accumulation mode particles associated with Asian dust in southwestern Japan, Atmos. Environ., 40, 1205-1215, 2006.

Zhang, R., Han, Z., Cheng, T., and Tao, J.: Chemical properties and origin of dust aerosols in Beijing during springtime, Particuology, 7, 61-67, 2009.

Zhou, M., Okada, K., Qian, F., Wu, P. M., Su, L., Casareto, B. E., and Shimohara, T.: Characteristics of dust-storm particles and their long-range transport from China to Japan - case studies in April 1993, Atmos. Res., 40, 19-31, 1996.

Zimmermann, F., Weinbruch, S., Schütz, L., Hofmann, H., Ebert, M., Kandler, K., and Worringen, A.: Ice nucleation properties of the most abundant mineral dust phases, J. Geophys. Res., 113, D23204, doi:10.1029/2008jd010655, 2008.

Zuberi, B., Bertram, A. K., Cassa, C. A., Molina, L. T., and Molina, M. J.: Heterogeneous nucleation of ice in $\left(\mathrm{NH}_{4}\right) 2 \mathrm{SO}_{4}-\mathrm{H}_{2} \mathrm{O}$ particles with mineral dust immersions, Geophys. Res. Lett., 29, 10, doi:10.1029/2001GL014289, 2002. 